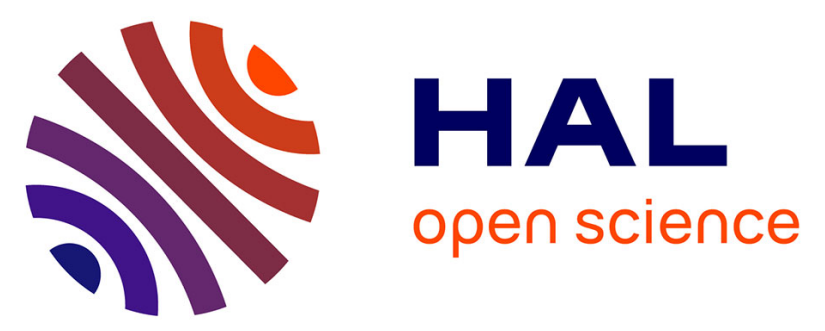

\title{
A Thermal Pulse Induced by a Permian Mantle Plume in the Tarim Basin, Northwest China: Constraints From Clumped Isotope Thermometry and In Situ Calcite $\mathrm{U}-\mathrm{Pb}$ Dating
}

Fuyun Cong, Jinqiang Tian, Fang Hao, Alexis Licht, Yuchen Liu, Zicheng

Cao, John M Eiler

\section{To cite this version:}

Fuyun Cong, Jinqiang Tian, Fang Hao, Alexis Licht, Yuchen Liu, et al.. A Thermal Pulse Induced by a Permian Mantle Plume in the Tarim Basin, Northwest China: Constraints From Clumped Isotope Thermometry and In Situ Calcite U-Pb Dating. Journal of Geophysical Research: Solid Earth, 2021, 126, 10.1029/2020jb020636 . hal-03426516

\section{HAL Id: hal-03426516 https://hal.science/hal-03426516}

Submitted on 12 Nov 2021

HAL is a multi-disciplinary open access archive for the deposit and dissemination of scientific research documents, whether they are published or not. The documents may come from teaching and research institutions in France or abroad, or from public or private research centers.
L'archive ouverte pluridisciplinaire HAL, est destinée au dépôt et à la diffusion de documents scientifiques de niveau recherche, publiés ou non, émanant des établissements d'enseignement et de recherche français ou étrangers, des laboratoires publics ou privés. 


\section{A thermal pulse induced by a Permian mantle plume in the Tarim Basin,}

\section{Southwest China: Constraints from clumped isotope thermometry and in-}

\section{situ calcite U-Pb dating}

\section{Fuyun Cong ${ }^{1,2,3}$, Jinqiang Tian², Fang Hao ${ }^{2}$, Alexis Lichtt,5, Yuchen Liu', Zicheng $\mathrm{Cao}^{7}$ and John M. Eiler ${ }^{3}$}

${ }^{1}$ Key Laboratory of Tectonics and Petroleum Resources, Ministry of Education, China University of Geosciences, Wuhan 430074, China

${ }^{2}$ Key Laboratory of Deep Oil and Gas, China University of Petroleum (East China), Qingdao 266580, China

${ }^{3}$ Division of Geological and Planetary Sciences, California Institute of Technology, Pasadena, California 91125, U.S.A.

${ }^{4}$ Department of Earth and Space Sciences, University of Washington, Seattle, Washington 98195, U.S.A.

5 Centre Européen de Recherche et d'Enseignement des Géosciences de l'Environnement (Cerege) UMR CNRS7330, 13545 Aix-en-Provence, France

${ }^{6}$ State Key Laboratory of Petroleum Resources and Prospecting, China University of Petroleum, Beijing 102249, China.

${ }^{7}$ Research Institute of Petroleum Exploration and Production, SINOPEC Northwest Company, Urumqi, Xinjiang 830011, China

* Corresponding author: Jinqiang Tian (tianjq@upc.edu.cn); Fang Hao (haofang@upc.edu.cn)

\section{Key Points:}

- $\Delta_{47}, \mathrm{U}-\mathrm{Pb}$ dating and solid-state reordering model as an integrated thermochronological tool suitable for deeply-buried carbonate intervals.

- Identified a previously ignored thermal pulse induced by mantle plume activity in the Tarim Basin.

- Using natural samples to constrain the sensitivity of solid-state reordering models to kinetic parameters. 


\begin{abstract}
High burial temperature and a lack of material for traditional thermal proxies significantly impede the understanding of the thermal history of carbonate stratigraphic sequences in deep time. Carbonate clumped isotope thermometry interpreted through models of solid-state isotopic reordering and in-situ $\mathrm{U}-\mathrm{Pb}$ dating provides a new methodology for reconstructing thermal histories of such successions. Calcite fabrics (micrite cements and veins) from deeply buried (5000-8000 m) Ordovician carbonate intervals in the Tarim Basin were analyzed for their carbonate clumped isotope compositions and $\mathrm{U}-\mathrm{Pb}$ ages, and the results were used to estimate maximum peak burial temperatures. Reconstructed burial temperatures reveal a previously ignored thermal pulse in the range of $160 \square-190 \square$ during the Permian period. Maximum geothermal gradients at the time of peak burial temperature varied from $26.8 \square / \mathrm{km}$ to $69.3 \square / \mathrm{km}$, with higher values in the northern Tarim Basin. We show that the spatial patterns of peak burial temperature and geothermal gradients closely correspond to the distribution of the Tarim Large Igneous Province, which emplaced during the Permian following the emplacement of a mantle plume beneath the Tarim Basin. We thus propose that the thermal pulse recorded in Tarim Ordovician limestones resulted from Permian mantle plume activity. The reconstructed thermal history has important implications for our understanding of source-rock hydrocarbon generating history, hydrocarbon accumulation and fluid flow history in the Tarim Basin. This study also demonstrates the potential of the integration of $\Delta_{47}, \mathrm{U}-\mathrm{Pb}$ dating of carbonates and solid-state reordering models as an integrated thermochronological method for reconstructing thermal histories of deeplyburied carbonate intervals.
\end{abstract}

\title{
1 Introduction
}

Reconstructing the thermal history of sedimentary basins is critical in basin analysis, geodynamic studies and energy resources exploration. However, the applicability of traditional thermal proxies (e.g. vitrinite reflectance, fission-track analysis, (U-Th)/He dating) are limited by specific material availability (e.g. vitrinite, zircon, apatite) or relatively high paleotemperature range, and are not practically applicable in deeply-buried Paleozoic carbonate successions.

Carbonate clumped isotope thermometry is a new and powerful technique for determining the thermal history of surface and shallow crustal processes, and can be measured on variety of solid carbonates (Eiler, 2007, 2011; Stolper and Eiler, 2015; Huntington and Lechler, 2015; Lloyd et al., 2017; Chen et al., 2019). The "clumping" of the heavy isotopes ${ }^{13} \mathrm{C}$ and ${ }^{18} \mathrm{O}$ with each other into the same carbonate ion is a temperature-dependent process and can be described as the following exchange reaction:

$$
\mathrm{Ca}^{13} \mathrm{C}^{16} \mathrm{O}_{3}+\mathrm{Ca}^{12} \mathrm{C}^{18} \mathrm{O}^{16} \mathrm{O}_{2}=\mathrm{Ca}^{13} \mathrm{C}^{18} \mathrm{O}^{16} \mathrm{O}_{2}+\mathrm{Ca}^{12} \mathrm{C}^{16} \mathrm{O}_{3}
$$

Under elevated burial temperatures and timescales of hundreds of millions of years, calcite exposed to temperature range above 75-100 $\square$ or dolomite to above 120$150 \square$, clumped isotope equilibria are susceptible to resetting through solid-state reordering of $\mathrm{C}-\mathrm{O}$ bonds, meaning that carbonate clumped isotope compositions could

This article is protected by copyright. All rights reserved. 
serve as a proxy for thermal evolution history (Passey and Henkes, 2012; Henkes et al., 2014; Stolper and Eiler, 2015; Lloyd et al., 2018; Ryb et al., 2017). The combination of kinetic parameters determined from laboratory heating experiments and kinetic models have been used to predict the extent to which solid-state reordering processes have altered the clumped isotope compositions as functions of thermal evolution scenarios (i.e. the first-order kinetic model of Passey and Henkes, 2012, the transient effect/equilibrium defect model of Henkes et al., 2014 and the exchange/diffusion model of Stolper and Eiler, 2015). These methods have been used to decipher the cooling rates of metamorphic marbles (Passey and Henkes, 2012; Ryb et al., 2017; Lloyd et al., 2017), burial and exhumation histories of sedimentary basins (Shenton et al., 2015; Gallagher et al., 2017; Mangenot et al., 2018a) and diagenesis processes (Lawson et al., 2018; Lacroix and Niemi 2019; Ingalls, 2019).

Recent carbonate $\mathrm{U}-\mathrm{Pb}$ dating using the laser ablation inductively coupled plasma mass spectrometry technique (LA-ICP-MS) have shown the potential of this method for constraining the chronology of calcite vein growth and diagenesis in carbonates (Roberts and Walker, 2016; Mangenot et al., 2018b; Parrish et al., 2018; Godeau et al., 2018; Hellwig et al., 2018). Carbonate in-situ U-Pb dating has been used to constrain the absolute timing of (re-)precipitation of carbonate minerals in deep time, under the assumption that they form a closed isotopic system and have a homogeneous initial (“common") Pb composition (Li et al., 2014; Roberts and Walker, 2016; Nuriel et al., 2017; Holdsworth et al., 2019a,b; Roberts et al., 2020). The combination of carbonate clumped isotopes and in-situ U-Pb dating has previously been applied in studies of paleoclimate and paleoenvironment (Methner et al., 2016; Quade et al., 2017; Pagel et al., 2018), fluid flow (MacDonald et al., 2019) and thermal histories of shallowly buried carbonate intervals (Mangenot et al., 2018b). Here, we integrate these two methods with solid-state reordering modeling, and explore its potential as a novel thermochronological tool to reconstruct the temperature-time evolution histories of deeply-buried carbonate intervals.

The Ordovician carbonate intervals of the Tarim Basin are important targets for hydrocarbon exploration, but are characterized by deep burial depth (5000 m to 8000 m) and high burial temperature $(>140 \square)$; these conditions hover near the upper edge of the 'oil window', with significant implications for hydrocarbon resources. Over the past few decades, the understanding of the burial and thermal histories of these deeply-buried intervals have been hampered due to a paucity of applicable thermal indicators and complex tectonic history. Some previous studies have suggested progressive burial and heating histories (e.g. Xu et al., 2018), while others have argued for a higher peak burial temperature in the geological past, either due to strong subsidence and subsequent intense uplift and erosion (e.g. Wang et al., 2010, Qiu et al., 2012), or associated with magmatic activity related to the mantle plume emplacement during Permian period, which may have imposed a pulse of high heat flow through the crust (e.g. Li et al., 2010; Li et al., 2016).

In this study, we combined carbonate clumped isotope analysis with in-situ $\mathrm{U}-\mathrm{Pb}$ dating on different generations of calcite fabrics in Ordovician carbonate intervals in the Tarim Basin, and fitted forward models of the thermal history to these data using

This article is protected by copyright. All rights reserved. 
existing solid-state reordering kinetic data. We reconstructed these thermal histories to address the following goals: (1) to establish a new thermochronological method to reconstruct thermal histories of deeply-buried carbonate intervals; (2) to investigate the approximate range and timing of peak burial temperatures in the Ordovician carbonate intervals; (3) to test the relative thermal effects of igneous activity (or mantle plume emplacement) vs. erosion on thermal evolution history; (4) and to use results from natural samples to constrain the sensitivity of different solid-state reordering models to kinetic parameters. The thermal histories we reconstruct have significant implications for the understanding of the regional tectono-thermal evolution history and hydrocarbon generation history of the Tarim Basin and similar basins worldwide.

\section{Geological Setting}

With an area of $56 \times 104 \mathrm{~km}^{2}$, The Tarim Basin is the largest inland basin in Northwestern China, bounded by the Tianshan orogenic belt to the north and northwest, the Kunlun orogenic belt to the southwest and the Altyn orogenic belt to the southeast (Li et al., 1996; Jia and Wei, 2002; Zhu et al., 2013; Yao et al., 2018) (Fig. 1a). It is a tectonically superimposed basin composed of a Paleozoic craton and Meso-Cenozoic foreland basins (Jia, 1997; Zhang et al., 2015). The Paleozoic craton comprises a Proterozoic basement overlain by Neoproterozoic to Cambrian sequences (Zhang et al., 2013). After the initial formation related to the breakup of Rodinia during the Neoproterozoic, the Tarim Basin switched between extensional and compressional tectonic regimes and has experienced multiple stages of intense tectonic activity (Jia et al., 1995; Jin et al., 2005; Lin et al., 2012; Zhang et al., 2013; He et al., 2016).

Figure 1. (a) Simplified distribution of tectonic units and Tarim Large Igneous Province (TLIP) in the Tarim Basin; inserted map shows the geographical location of Tarim Basin in China. (b) Enlarged view of the study area showing the distribution of sampling wells. (c) Cross-well Paleozoic stratigraphic profile including TS301, TP18, SHB2, ST1, SN4, SN5-2 and GL3 wells. Logging data were provided by SINOPEC Northwest Company. Note the thick igneous rocks developed on top of Permian strata in wells TP18 to ST1, eroded away in TS301 well, and absent in SN4 to GL3 wells. Detailed lithology was simplified based on logging data provided by SINOPEC Northwest Company.

The Tarim Basin consists of four depressions (i.e. the Kuqa depression, the Northern depression belt, the Southwestern depression belt and the Southeastern depression belt) and three uplifted regions (i.e. the Tabei uplift belt, the Central uplift belt and the Southeastern uplift belt) (Li et al., 1996; Jia and Wei, 2002; Yu et al., 2011) (Fig.1a). Bounded by the Awati depression to the Northwest and the Manjiar depression to the Northeast, the Shuntuoguole low uplift belongs to the Northern depression belt and is composed of four structural units: the Shunbei, Shuntuo,

This article is protected by copyright. All rights reserved. 
Shundong and Shunnan areas (Huang, 2014; Lü et al., 2017; Deng et al., 2019) (Fig. 1b, Fig. 2).

Figure 2. Cross section showing the structural framework of the Shuntuoguole low uplift. Section location in Fig. 1b. (modified from unpublished seismic profile provided by SINOPEC Northwest Company)

The sedimentary filling history of the basin includes the deposition of marine to non-marine facies during the Neo-Proterozoic era to Early Permian epoch and terrestrial facies during the Late Permian epoch to the Quaternary period (Li et al., 1996; Jia and Wei, 2002). Carbonate sediments dominate in the Lower Paleozoic intervals from Cambrian to Middle-Lower Ordovician, whereas the Upper Ordovician intervals are composed of thick dark gray mudstone with thin limestone interlayers (Jiang et al., 2016; Shen et al., 2019) (Fig. 3). The Middle-Lower Ordovician Yijianfang and Yingshan Formations are the main studied intervals and mainly consist of dolomitic limestone and limestone (Cai and Li, 2008; Lu et al, 2017) (Fig. 3).

Figure 3. Generalized stratigraphic column showing the Paleozoic strata and discordances in the northern part in the Tarim Basin (modified from Yao et al., 2018).

Igneous rocks are widely distributed in the Permian strata of the basin and are referred to as the Tarim Large Igneous Province (TLIP) (Yang et al., 2013; Xu et al., 2014), which covers an area of more than $250,000 \mathrm{~km}^{2}$ (Fig.1a). Petrological studies have suggested a genetic link of the Large Igneous Province to a deeply emplaced mantle plume (Wei et al., 2014; Xu et al., 2014; Yang et al., 2013; Zhang et al., 2016). Previously published geochronological data indicate that the major phase of the TLIPrelated magmatism began at ca. $292 \mathrm{Ma}$ and ended around $269 \mathrm{Ma}$, with an earliest minor pulse initiating around $300 \mathrm{Ma}$ (Yang et al., 2013; Li et al., 2014; Xu et al., 2014; Zhang et al., 2016) (Fig. 4). In the studied areas, the thickness distribution of the igneous rock is highly variable, ranging from 0 to $530 \mathrm{~m}$, thickest in the Shunbei and Shuntuo areas, thinning Northward and eroded away in the Tabei area and absent in the Shunnan and Gulong areas (Fig. 1c).

Figure 4. Compilation of major tectonic events, erosion intensity and igneous events in the Tarim Basin since $500 \mathrm{Ma}$. Tectonic and igneous event chronology is from $\mathrm{He}$ et al., (2011), Zhang et al. (2013) and He et al., (2016). Erosion events refers to Lin et al., (2012) and Liu et al., (2015). Ages of Permian Large Igneous Province (LIP) are

This article is protected by copyright. All rights reserved. 
zircon U-Pb ages from Zhang et al., (2016). Erosion thickness refers to thickness of strata eroded during uplifting.

\section{Samples and Methods}

\subsection{Samples}

We collected a series of calcite samples from Middle-Lower Ordovician Yijianfang and Yingshan Formations from drill-cores of seven different wells, distributed across the Tabei area (i.e. TS301 and TP18 wells), Shunbei area (i.e. SHB2 well), Shuntuo area (i.e. ST1 well), Shunnan area (i.e., SN4 and SN5-2 wells) and Gulong area (i.e. GL3 well) (Fig.1B). These wells provide representative coverage of the Tabei uplift and Shuntuoguole low uplift (Fig.1B). Three different calcite fabrics (i.e. micrite, voidfilling cements, and veins) were collected from the same rock for the analysis of clumped isotope compositions, to examine whether all fabric components experienced identical burial and thermal histories (Fig.5). Fossils large enough for isotopic analysis were not found in drill-cores and were not included. Calcite fabric samples were milled using a hand Dremel with drill bits of $0.5 \mathrm{~mm}$ and $1 \mathrm{~mm}$ and homogenized before aliquoting for isotope analysis. We carefully avoided areas with factures and stylolites and only drilled in the center of the listed fabrics to avoid the mixing of different diagenetic components. Bulk rock powder milled using agate mortar and pestle were used for XRD analysis to determine proportions of mineral types. Solid bitumen preserved in carbonate rocks collected from the same stratigraphic intervals were measured for bitumen reflectance $\left(\mathrm{R}_{\mathrm{b}}\right)$ using Laser Ramen Spectroscopy.

\subsection{Cathodoluminescence analyses}

Cathodoluminescence microscopy is often used to constrain the origins of diagenetic materials. Calcite luminescence reflects the trace elements abundances in the crystal lattice, with $\mathrm{Mn}^{2+}$ ions activating and $\mathrm{Fe}^{2-}$ ions quenching luminescence (Machel, 1985). Cathodoluminescence (CL) studies were carried out on doubly polished sections on a CL8200 Mk5-2 optical Cathodoluminescence system in the Key Laboratory of Tectonics and Petroleum Resources, China University of Geosciences, Wuhan, using an electron gun current of about $300-500 \mu \mathrm{A}$ and an acceleration voltage of 5-8 kV.

\subsection{X-ray diffraction analyses (XRD)}

X-ray diffraction analyses were made on bulk sample powders on an X'Pert Pro DY2198 at the State Key Laboratory of Geological Process and Mineral Resources, in the China University of Geosciences. The samples were ground into powders smaller than 200 meshes ( 75 microns in diameter). XRD patterns were recorded by a Rigaku $\mathrm{D} / \mathrm{max}-\mathrm{rA}$ diffractometer with $\mathrm{Cu} \mathrm{K} \alpha$ radiation.

\section{$3.4 \delta^{13} \mathrm{C}, \delta^{18} \mathrm{O}$ and clumped isotope measurements}

20 samples were analyzed for the stable isotopes $\left(\delta^{13} \mathrm{C}, \delta^{18} \mathrm{O}\right)$ and clumped isotopes $\left(\Delta_{47}\right)$ using a Thermo Scientific MAT 253 IRMS at the California Institute of Technology, following the procedures outlined in Passey et al. (2010), and Ryb et al.,

This article is protected by copyright. All rights reserved. 
(2018). 8-15 mg of carbonate powder was weighed into silver capsules for each measurement. Most samples were replicated three times on the same carbonate powder, amounting to a total of 55 measurements. However, as this was not always possible (e.g., for certain small cements and veins), some samples were analyzed only once or twice. The powders were dissolved in a $103 \%$ phosphoric acid bath for 20 min at $90 \square$. Evolved $\mathrm{CO}_{2}$ was collected and purified through an automated system using traps immersed in dry ice/ethanol and liquid $\mathrm{N}_{2}$ baths, and passed through a Porapak-Q 120/80 mesh column (-20 $\square$ ) with a helium carrier gas. The purified $\mathrm{CO}_{2}$ gas was measured for relative abundances of masses 44, 45, 46, 47, 48 and 49 on the Thermo MAT 253 IRMS. Each measurement consisted of eight acquisitions of seven cycles of comparison of sample $\mathrm{CO}_{2}$ gas with Oztech working gas. Gases equilibrated at $1000 \square$ or $25 \square$ were measured concurrently with sample measurements (i.e, within the same span of days) to generate the data required to present sample measurements in the absolute reference frame and to correct for non-linearity and source scrambling (Dennis et al., 2011). The raw measured isotope ratios were normalized into the absolute reference frame using the ClumpyCrunch v1.0 online calculator (Daeron et al., 2011). An acid fractionation factor of $0.092 \%$ (Henkes et al., 2013) was added to $\Delta_{47}$ values in order to report values on the $25 \square-\Delta_{47} \mathrm{scale}$. In addition, we concurrently measured in-house carbonate standards CIT Carrara and TV04, which yielded average $\Delta 47$ values and SDs of $0.405 \pm 0.017 \%$ and $0.662 \pm$ $0.018 \%$, respectively.

The variable $\Delta_{47}$ is used to describe the deviation of the relative abundance of mass $47 \mathrm{CO}_{2}$ isotopologues in carbonate samples $\left(\mathrm{R}_{47}\right)$ from the $\mathrm{R}_{47}$ value expected for the same bulk isotopic composition if the sample had a stochastic distributed of all isotopes among all isotopologues $\left(\mathrm{R}^{*}{ }_{47}\right)$. In thermodynamically equilibrated materials, $\Delta_{47}$ is a function of temperature, with decreasing $\Delta_{47}$ values associated with increasing temperatures. Values of $\Delta_{47}$ in the absolute reference frame were converted into apparent temperatures (i.e., the temperatures that would correspond to equilibrium for the measured $\Delta_{47}$ value) using the calibration equation of Bonifacie et al. (2017), which has been previously shown to provide accurate results for data generated in the Caltech labs. Temperatures based on the theoretical $\mathrm{T}\left(\Delta_{47}\right)$ calibration of Schauble et al. (2006) are also presented for solid-state reordering model calculations, consistent with the calibration used in the derivation of reordering model of Stolper and Eiler (2015). Indeed, the Stolper and Eiler (2015) reordering model was fit and run in the Caltech intralaboratory reference frame, which is compressed relative to the absolute reference frame by about $10 \%$, and is thus incompatible with absolute reference frame data.

$\delta^{13} \mathrm{C}$ and $\delta^{18} \mathrm{O}$ values of the carbonate samples are expressed with respect to the VPDB (Vienna Peedee Belemnite) reference standard. Isotopic compositions of waters in equilibrium with carbonates at their nominal apparent temperatures were calculated using the measured clumped isotope temperatures calibration equation of Bonifacie et al. (2017) and the equilibrium calcite-water fractionation of O'Neil et al. (1969). The $\delta^{18} \mathrm{O}_{\text {water }}$ values are expressed relative to VSMOW (Vienna Standard Mean Ocean Water).

This article is protected by copyright. All rights reserved. 


\subsection{Equivalent vitrinite reflectance}

Due to a lack of vitrinite originating from higher plants in the Lower Paleozoic carbonate intervals, only bitumen reflectance $\left(\mathrm{R}_{\mathrm{b}}\right)$ of samples from four wells was measured, and was converted to equivalent $R_{0}\left(R_{\text {equ }}\right)$ using the formula from Liu and Shi (1994) if $\mathrm{R}_{\mathrm{b}}>2.0 \% \mathrm{~m}$ and the formula from Jacob (1989) if $\mathrm{R}_{\mathrm{b}}<2.0 \%$.

For samples from TP18 and SHB2, solid bitumen preserved in the pore spaces was analyzed by laser Raman spectroscopy at the China University of Petroleum, East China on polished thin sections. The Raman spectral parameters, including band positions (D and G), heights of the D and G bands, saddle index (ratio of height of the $\mathrm{G}$ band to the minimum between the $\mathrm{G}$ and $\mathrm{D}$ bands) and full width at half mean for a given band are selected to evaluate the equivalent reflectance. Details of Raman maturity evaluation methods can be found in Wilkins et al. (2014). For samples from the $\mathrm{ST} 1, \mathrm{SN} 4$ and GL3 wells, bitumen reflectance $\left(\mathrm{R}_{\mathrm{b}}\right)$ data was provided by the SINOPEC Northwest Company (Urumqi); these data were measured under reflected light on a microphotometric system.

\subsection{Calcite U-Pb dating}

Carbonate samples were first cut to expose fresh surfaces and then incorporated into a 1-inch epoxy mount. The mounts were then manually polished, first with coarse (38 $\mu \mathrm{m}$ grit size) then fine ( $5 \mu \mathrm{m}$ grit size) sandpaper.

$\mathrm{U}-\mathrm{Pb}$ dating was conducted by laser ablation inductively coupled plasma mass spectrometry (LA-ICPMS) at the TraceLab laboratory of the University of Washington; details about the LA-ICPMS hardware can be found in Licht et al. (2018). The analyses were performed by ablation with an Analyte G2 excimer laser using a spot diameter of $50 \mu \mathrm{m}, 20 \mathrm{~Hz}$ pulse repetition rate and an energy fluence of $2.94 \mathrm{~J} \mathrm{~cm}^{-2}$. The ablated material was carried in helium and mixed with nitrogen into the plasma source of an iCAP RQ Quadrupole ICP-MS. Our data acquisition procedure closely follows the one of Drost et al. (2018). Samples were ablated along parallel linear scans of 5 to $20 \mathrm{~mm}$ length at $10 \mu \mathrm{m} . \mathrm{s}^{-1}$. Linear scans are arranged in successive order, with no overlaps or gaps between line scans, covering areas of $5 \times 5$ to $20 \times 20 \mathrm{~mm}^{2}$. Analyzed masses include ${ }^{238} \mathrm{U},{ }^{235} \mathrm{U},{ }^{232} \mathrm{Th},{ }^{207} \mathrm{~Pb},{ }^{206} \mathrm{~Pb},{ }^{204} \mathrm{~Pb},{ }^{24} \mathrm{Mg}$ and ${ }^{40} \mathrm{Ca}$, with a total combined dwell time of $\sim 0.4 \mathrm{~s}$. Analyses of the linear scans of the calcite standard WC-1 (Roberts et al., 2017) and synthetic glass NIST 612 reference material are used to bracket analyses of unknowns.

Data reduction follows the procedure of Parrish et al. (2018) is conducted with Iolite, using the Trace_Elements scheme to get elemental concentrations and the Geochron Data Reduction Scheme without downhole fractionation correction to get $\mathrm{U} / \mathrm{Pb}$ isotopic ratios (Paton et al., 2010). NIST 612 standard glass is used as the primary reference material for calibration of both reduction schemes. We then manually select $>20$ portions of scan per sample in Iolite by monitoring individual data channels, covering a broad range of ${ }^{238} \mathrm{U} /{ }^{206} \mathrm{~Pb}$ values and making sure that every portion is at least $2 \mathrm{~s}$ long and has no jump in ${ }^{238} \mathrm{U} /{ }^{206} \mathrm{~Pb},{ }^{207} \mathrm{~Pb} /{ }^{206} \mathrm{~Pb}$, and ${ }^{24} \mathrm{Mg} /{ }^{40} \mathrm{Ca}$ ratios. The isotopic results from these portions of scan make individual analyses that are loaded into an MS Excel spreadsheet with the Isoplot add-on (Isoplot 4.15;

This article is protected by copyright. All rights reserved. 
Ludwig, 2012) and a macro for matrix-dependent $\mathrm{U}-\mathrm{Pb}$ fractionation correction from Parrish et al. (2018), based on 612-normalized WC-1 carbonate data (WC-1 correction factor during the analytical session: 1.096). The additional uncertainty related to WC-1 final normalization $(0.7 \% 2 \mathrm{SE})$ is quadratically added to all individual analysis uncertainties. A linear regression of the individual analysis in Tera-Wasserburg space is then undertaken for each sample to obtain its initial ${ }^{207} \mathrm{~Pb} /{ }^{206} \mathrm{~Pb}$ ratio, the lower intercept date, and their associated uncertainties using Isoplot. Uncertainties on the U-Pb dates ratios are given at the $2 \mathrm{SE}$ confidence level throughout this paper. Uncertainties are measurement uncertainties and do not include the systematic uncertainty calculated from the long-term reproducibility of secondary reference materials, as no other carbonate reference material but the WC-1 standard as been so far published. The systematic uncertainty based on the long-term reproducibility of 10 zircon reference materials is of $\sim 2.67 \%(2 \sigma)$ for ${ }^{238} \mathrm{U} /{ }^{206} \mathrm{~Pb}$ ratios at the University of Washington (Licht et al., 2020). All U-Pb data and analytical details are reported in supporting information Dataset $\mathrm{S} 1$.

\subsection{Burial history and thermal history modeling}

Models of thermal history are founded on stratigraphic estimates of burial history. To construct burial histories, thickness, depths, and average lithologies in the wells were taken from the well completion reports provided by SINOPEC. Erosion events and the according eroded thickness were constrained independently by geophysical methods (e.g. via seismic reflection data and well logs) by previous studies and are site-specific; the details are not reviewed here. Specifically, the erosion timing and thickness for wells in the Tabei area (i.e. TS301 and TP18 well) Shunbei area (i.e. SHB2 well) and Shuntuo area (ST1 well) were taken from Liu et al. (2015), the erosion events for wells in the Shunnan area (i.e. SN4 and SN5-2 well) were from Wang et al. (2014), and the erosion events for wells in the Gulong area (i.e. GL3 well) were from $\mathrm{Wu}$ (2015) (Fig. S1).

BasinMod 1-D software was used to develop the base case thermal histories of the studied wells (Platte River Associates Inc., 2003), which considers the combined effects of burial history, heat flow, and thermal conductivity to build a base case thermal history, which is later modified to fit clumped isotope and equivalent vitrinite reflectance data. Initial estimates of heat flow change through time of each well was estimated based on the reference values suggested by Qiu et al., (2002) and Li et al., (2010). Published thermal conductivity data for different lithology types (Feng et al., 2009) were integrated into the model and default parameters in the BasinMod 1-D software were used for the initial porosity, matrix density and heat capacity. The bottom hole temperature (BHT) and temperatures obtained during well tests (DST) were used for calibration.

\section{Results}

4.1 Petrographic and XRD characteristics

All samples were collected from drilling wells at depths of $6127.10 \mathrm{~m}$ to 7861.33

This article is protected by copyright. All rights reserved. 
$\mathrm{m}$ (Table 1). The present-day burial temperatures for sampled intervals of each well range from $131 \square$ to $191 \square$ and are given in Table 2. Micrite are dense and uniform in texture both in hand specimen and under plain light microscope, but contain different kinds of bioclast fragments, with sizes of 0.05-0.2mm (Fig. 5). Three types of cathodoluminescent patterns for micrite have been recognized: non-luminescence (NL), patchy-luminescence (PL) and bright-luminescence (BL). Only the micrite with non-luminescence (NL) and patchy-luminescence (PL) patterns were selected for stable and clumped isotope analysis and $\mathrm{U}-\mathrm{Pb}$ dating, in order to eliminate the influence of diagenesis/recrystallization during burial (Fig. 5; Fig. S2-S15). Voidfilling cements and veins are scarce and were sampled for isotope analysis without complementary thin sections and cathodoluminescence photomicrographs. The XRD results showed that the studied limestones are mostly composed of calcite (>94\%) with a tiny proportion of quartz, dolomite and ankerite (Fig. 6).

Figure 5. Hand specimens, thin-sections and photomicrographs under transmitted light and cathodoluminescence microscopy (CL) of parts of the samples used for measurements. Red dots indicate areas for in-situ calcite U-Pb dating, and yellow indicate areas for clumped isotope measurements. NL: non-luminescence, PL: patchyluminescence, BL: bright-luminescence.

\subsection{Stable isotope compositions}

Stable isotope data for the 20 samples measured in this study are reported in Table 1 and Fig. 5 with 1 SD. The total range of the stable isotope compositions of all measured samples are in the range of $-3.08 \%$ o to $0.55 \%$ o for $\delta^{13} \mathrm{C}$ and $-9.93 \%$ o to $3.57 \%$ or $\delta^{18} \mathrm{O}$, showing great variability among different diagenetic phases and little covariation between $\delta^{13} \mathrm{C}$ and $\delta^{18} \mathrm{O}$ (Fig. 6; Fig. 7a). For micrite matrix, the range of $\delta^{13} \mathrm{C}$ and $\delta^{18} \mathrm{O}$ are $-3.08 \%$ o to $0.21 \%$ and $-7.60 \%$ o to $-5.50 \%$, respectively, and low covariance is observed $\left(\mathrm{R}^{2}=0.267\right)$. For void-filling cements, the range of $\delta^{13} \mathrm{C}$ and $\delta^{18} \mathrm{O}$ are $-0.85 \%$ o to $0.00 \%$ and $-7.25 \%$ o to $-3.57 \%$, respectively. For veins, the range of $\delta^{13} \mathrm{C}$ and $\delta^{18} \mathrm{O}$ are $-2.37 \%$ to $0.55 \%$ and $-9.93 \%$ o to $-6.57 \%$, respectively. The isotope ranges of each of the three different diagenetic phases are generally similar to one another (though non-overlapping extremes with distinct combinations of $\delta^{13} \mathrm{C}$ and $\delta^{18} \mathrm{O}$ values are observed). The summarized $\delta^{13} \mathrm{C}$ and $\delta^{18} \mathrm{O}$ ranges of carbonate fabrics for each well are presented in Table 2. For comparison, we also present in Figure 7A the $\delta^{13} \mathrm{C}$ and $\delta^{18} \mathrm{O}$ values of 89 well-preserved Paleozoic brachiopod shells from a global compilation of samples from tropical-subtropical regions from Floian to Darriwilian stages, spanning ages from 463.46 to $473.08 \mathrm{Ma}$ (Wadleigh and Veizer, 1992; Qing and Veizer, 1994; Veizer et al., 1999; Grossman, 2012), and 207 previously published measurements of nominally unaltered fossils and micrite matrix from the Yijianfang and Yingshan Formations in the Tarim Basin (Zhang and Munnecke, 2016) (Fig. 7a).

This article is protected by copyright. All rights reserved. 
Figure 6. Summary of stable isotope, clumped isotope data and cathodoluminescence microscopy (CL) and X-ray diffraction (XRD) results for each sample. Errors of $\delta^{13} \mathrm{C}$ and $\delta^{18} \mathrm{O}$ are reported as $1 \mathrm{SD}$ of replicate analyses, and errors of $\Delta_{47}, \mathrm{~T} \Delta_{47}$ are reported as $1 \mathrm{SE}$ of replicate analyses. For singly measured samples, the errors are reported using internal measurement standard deviations or standard errors. VPDBVienna Peedee Belemnite. VSMOW - Vienna standard mean ocean water. N number of replicates for isotope analysis. CT 1-20 are analytical numbers assigned to each sample during isotopic measurements; more details for each sample is provided in Table 1. Samples were sorted based on fabrics and sampling depth, consistent with sample order in Table 1. Requ一equivalent Ro determined by laser Raman spectroscopy.

\subsection{Clumped isotope thermometry and organic maturity}

The results of measured clumped isotope values and derived temperatures for each sample and the average values for each well are provided in Table 1 and Table 2, respectively. $\Delta_{47}$ values of all measured samples range from $0.418 \%$ o to $0.565 \%$, corresponding to apparent temperature estimates of $76 \square$ to $186 \square$ when applying the temperature calibration equation of Bonifacie et al. (2017), and of $72 \square$ to $177 \square$ applying the theoretical temperature calibration equation of Schauble et al. (2006). The $\Delta_{47}$ apparent temperatures for samples with NL and PL luminescence patterns display an obvious bimodal distribution, with $\Delta_{47}$ apparent temperatures of the micrite samples from wells in Tabei and Shunbei having an average of $72 \square$ to $94 \square$, significantly cooler than that in Shuntuo and Shunnan areas (i.e. $147 \square$ to $177 \square$ ).

Based on the calcite-water oxygen isotope thermometry equation from O'Neil et al. (1969), the parent water $\delta^{18} \mathrm{O}$ (SMOW) compositions $\left(\delta^{18} \mathrm{O}_{\mathrm{w}}\right)$ that were expected to be in equilibrium with each calcite fabrics were back-calculated using $\Delta_{47}$ apparent temperatures and measured mineral $\delta^{18} \mathrm{O}$ values (Table 1,2 ). The calculated $\delta^{18} \mathrm{O}_{\mathrm{w}}$ values for all samples range from $4.03 \%$ o to $15.44 \%$ (Table 1, 2 and Fig. $7 b$ ).

Figure 7. Summary of stable isotope, clumped isotope data and cathodoluminescence microscopy (CL) and X-ray diffraction (XRD) results for each sample. Errors of $\delta^{13} \mathrm{C}$ and $\delta^{18} \mathrm{O}$ are reported as $1 \sigma$ standard deviations of replicate analyses, and errors of $\Delta_{47}, \mathrm{~T} \Delta_{47}$ and $\delta^{18} \mathrm{O}_{\text {water }}$ are reported as $1 \mathrm{SE}$ of replicate analyses. For singly measured samples, the errors are reported using internal measurement standard deviations or standard errors. VPDB — Vienna Peedee Belemnite. VSMOW—Vienna standard mean ocean water.

The solid bitumen in Yijianfang and Yingshan Formations of samples from TP18, SHB2, ST1 and SN4 wells yielded average equivalent vitrinite reflectance ( $\left.\mathrm{R}_{\text {equ}}\right)$ of $1.62,1.56,1.78,1.86$ and 2.23 , respectively.

This article is protected by copyright. All rights reserved. 


\subsection{Calcite $\mathrm{U}-\mathrm{Pb}$ ages}

The ages of analyzed calcite samples are presented in Fig. 8. The average $\mathrm{U}$ and $\mathrm{Pb}$ content ranges from 6 to $2551 \mathrm{ppb}$ and from 23.36 to $385 \mathrm{ppb}$, respectively. The ${ }^{207} \mathrm{~Pb} /{ }^{206} \mathrm{~Pb}$ and ${ }^{238} \mathrm{U} /{ }^{206} \mathrm{~Pb}$ ratios of the samples show ranges from 0.066 to 0.94 and from 0 to 28.54 , respectively.

Figure 8. Tera-Wasserburg concordia plots showing ${ }^{238} \mathrm{U} /{ }^{206} \mathrm{~Pb}$ versus ${ }^{207} \mathrm{~Pb} /{ }^{206} \mathrm{~Pb}$ by in-situ U-Pb dating for micrites. MSWD-mean standard weighted deviation. Note that the red dashed line in the Tera-Wasserburg concordia plot of sample TP18$6827.02 \mathrm{~m}$ represent the $\mathrm{U}-\mathrm{Pb}$ isochron after rejecting outliers (outliers identified in supplementary table 1).

In-situ U-Pb ages determined from the lower intercepts on Tera-Wasserburg plots yielded results between $442 \pm 24 \mathrm{Ma}$ and $484 \pm 11 \mathrm{Ma}$ (Fig. 8). The ages are statistically reliable with low MSWD (mean standard weighted deviation) between 1.4 and 2.2. Specifically, the U-Pb ages cluster at $474.7 \pm 8.7 \mathrm{Ma}$ for the micrite sample from the TS301 well, $484 \pm 11 \mathrm{Ma}$ and $458 \pm 14 \mathrm{Ma}$ for two micrite samples from the TP18 well, $471 \pm 20$ Ma for the micrite sample from the SHB2 well, $464.8 \pm$ 4.8 Ma for the micrite sample from the ST1 well, $442 \pm 24$ Ma for the micrite sample from the SN4 well and 449.9 \pm 8.8 Ma for the micrite sample from the GL3 well. These ages either fall into the range of depositional ages of 477.7-471.8 Ma for the Yingshan Formation and of 471.8-458.4 Ma for the Yijianfang Formation (e.g. samples from TS301, TP18 and SHB2 wells) as constrained by biostratigraphy (Chen and Shi, 2003), or show slightly younger ages representing early recrystallization overprinting events (e.g. samples from ST1, SN4 and GL3 wells). The sample from depth $6827.02 \mathrm{~m}$ of TP18 well yields a U-Pb age slightly older than the depositional age but has also the highest MSWD (2.2) of all our calculated ages. Rejecting outliers falling the furthest away from the isochron (16 out of 73) brings down the MSWD to 1.4 and corrects the age to $471 \pm 11 \mathrm{Ma}$, which overlaps with the formation depositional age (Fig. 9). One core sample from well SHB2 (depth 7523.93m) yields a $\mathrm{U}-\mathrm{Pb}$ age which is more puzzling: $507.5 \pm 7.3 \mathrm{Ma}$, which is at least 20 million years older than the depositional age, while having a low MSWD (1.3) and no clear outlier datapoint. Though we could not identify a clear change of carbonate mineralogy in this sample, most samples from well SHB2 display some of non-calcite minerals, such as dolomite and ankerite (Fig. 6). We thus suspect that the slight age misfit might be related to changes of texture or mineralogy.

Figure 9. Summary of measured calcite $\mathrm{U}-\mathrm{Pb}$ ages. Dated $\mathrm{U}-\mathrm{Pb}$ ages are compared with depositional ages to identify possible diagenetic alteration.

This article is protected by copyright. All rights reserved. 


\section{Discussion}

\subsection{Evaluation of diagenetic overprinting}

Judging from the and present-day burial temperature, our samples are independently known to have experienced burial heating above the temperature threshold for solid-state reordering (i.e., $\sim 75^{\circ} \mathrm{C}-100^{\circ} \mathrm{C}$ ) over million-year timescales (Passey and Henkes, 2013; Henkes et al., 2014; Stolper and Eiler, 2015); we thus expect that our samples have experienced some degree of solid-state reordering. This fact readily explains why the studied micrite samples are characterized by apparent $\mathrm{T} \Delta_{47}$ values much higher than Phanerozoic marine temperatures (e.g. Veizer and Prokoph, 2015). However, it is also possible that elevated apparent $\mathrm{T} \Delta 47$ values reflect recrystallization processes or other heterogeneous reactions, in which case they cannot be interpreted in the context of thermal models based on solid-state reordering kinetics. Therefore, we need to evaluate the potential effects of diagenetic overprinting on our samples prior to proceeding with thermal history modeling.

Micrite matrix in marine limestones is commonly believed to record at least some geochemical properties of the ocean water from which it precipitated, and is a widely used archive for paleoclimate and paleoenvironmental reconstructions (Bartolini et al., 1999; Kasemann et al., 2005; Rais et al., 2007; Coimbra et al., 2009; Martin et al., 2012; Guido et al., 2016; Gao et al, 2018). However, micrite can be chemically altered through recrystallization during burial and extensive recrystallization has been suggested to have occurred on Paleozoic carbonates (Gao and Land, 1991; Land and Lynch, 1996; Joachimski et al., 2004; Cummins et al., 2014; Bennett et al., 2018; Ryb and Eiler, 2018).

Petrographic observation is one way to evaluate diagenetic alteration. All samples showing clear marks of recrystallization have been eliminated through our sample screening (Fig. 5). All of the samples we have analyzed have dense, fine, equigranular textures in transmitted light microscopy. They were pre-selected to have nonluminescence (NL) or patch-luminescence (PL) patterns, and excluded if they displayed evidence for several episodes of calcite growth in luminescence.

Carbonate $\delta^{18} \mathrm{O}$ and $\delta^{13} \mathrm{C}$ values in our samples do not show obvious co-variation, and are similar to previously published results of global and regional variations in $\delta^{18} \mathrm{O}$ and $\delta^{13} \mathrm{C}$ for nominally unaltered marine fossils of similar age (Fig. 7A). Yet, a clear positive correlation is observed in the plot of apparent $\mathrm{T} \Delta_{47}$ versus $\delta^{18} \mathrm{O}$ of water calculated for each sample, with apparent $\mathrm{T} \Delta_{47}$ increasing along contours of constant $\delta^{18} \mathrm{O}_{\text {carb }}$ (Fig. 7B). This behavior has been suggested to be either an artifact of solidstate diffusion during heating (i.e., clumped isotope composition changes with no heterogeneous isotope exchange with waters or other phases) or by rock-buffered diagenesis/recrystallization (Eiler, 2011; Finnegan et al., 2011; Ferry et al., 2011; Huntington et al., 2011; Huntington and Lechler, 2015; Cummins et al., 2014; Henkes et al., 2014, 2018). Both of these processes result in elevated $\mathrm{T} \Delta_{47}$ values without change in carbonate $\delta^{18} \mathrm{O}$, and hence lead to higher calculated $\delta^{18} \mathrm{O}_{\text {water values. Note }}$ that some cement and vein samples fall off the main trend for our data, indicating that some carbonate fabrics precipitated during burial diagenesis and experienced higher

This article is protected by copyright. All rights reserved. 
local integrated fluid/rock ratios (and confirming the ability of coupled clumped isotope and $\delta^{18} \mathrm{O}$ measurements to recognize such fabrics).

Despite the preceding evidence, we still cannot rule out the possibility that some of our micrite samples may have clumped isotope apparent temperatures that reflect conditions of diagenetic alteration/recrystallization. However, in-situ calcite $\mathrm{U}-\mathrm{Pb}$ dating technique provides another complementary constraint on this issue, as any late episode of diagenetic alteration/recrystallization would be reflected in $\mathrm{U}-\mathrm{Pb}$ ages younger than the depositional ages (Rasbury and Cole, 2009; Godeau et al., 2018; Pagel et al., 2018; Mueller et al., 2020) (Fig. 8, 9).

The U-Pb dates obtained on calcite micrite samples from TS301, TP18 and SHB 2 wells are consistent with the ranges of depositional ages, implying that they are either unaltered after deposition or only suffered from very early recrystallization (Fig. 9). Either way, the temperature and timing of their precipitation should not deviate far from unaltered marine carbonate, and their elevated clumped isotope apparent temperatures must be ascribed to solid state reordering. U-Pb dates of samples from the ST1, SN4 and GL3 wells are younger than the depositional age of their formation by up to $20 \mathrm{Myr}$. Although partial resetting of the U-Pb system during diagenetic alteration (i.e. with only $\mathrm{U}$ loss/ $\mathrm{Pb}$ gain or $\mathrm{U}$ gain/ $\mathrm{Pb}$ loss) could result in erroneous ages too young or too old than "right" ages (Rasbury and Cole, 2009), partial diagenetic alteration results in ages associated with high MSWD (commonly above 2.5 and up to several 100's), much larger than produced by reasonable initial heterogeneity (Rasbury and Cole, 2009). This is not the case in our studied samples, which all display low MSWDs. Therefore, it is likely that our samples have a simple diagenetic history with only one single (and early) recrystallization event (Fig. 9).

5.2 Thermal history reconstruction by clumped isotope reordering modeling and equivalent vitrinite reflectance

The evidence discussed in the previous section leads us to conclude that some of our micrite samples escaped late, high-temperature diagenetic recrystallization and thus have apparent $\mathrm{T} \Delta_{47}$ values that reflect solid-state reordering during burial and heating. Thus, their apparent temperatures provide a measure of their temperaturetime evolution, i.e., because their extent of solid-state reordering must reflect a combination of their kinetics of reordering (constrained by prior experiments) and their temperature-time histories. It follows that we can use these data to reconstruct temperature-time evolution histories, based on the following pieces of evidence.

First, the apparent T $\Delta_{47}$ of samples from Tabei area (TS301 and TP18 wells), Shunbei area (SHB2 well) and Shuntuo area (ST1 well) are much lower than the blocking temperature of slowly cooled marbles (i.e. $150 \square-200 \square$; Ghosh et al., 2006, Stolper and Eiler, 2015) and the modeled apparent equilibrium blocking temperature of sedimentary calcite using solid-state reordering models (i.e. 150 $\square-170 \square$; Henkes et al., 2014; Huntington et al., 2014). Moreover, most of the analyzed samples exhibit $\Delta_{47}$ apparent temperatures lower than their present-day burial temperature (Fig. 10). As full equilibration would require the final apparent $\mathrm{T} \Delta 47$ to be identical with the environment temperature if the peak burial temperature is the present-day burial

This article is protected by copyright. All rights reserved. 
temperature (According to Fig. 5 of Henkes et al., 2014 and Fig. 2B of Stolper et al., 2015), or to reside between the peak temperature and environment temperature if the peak burial temperature was a higher thermal anomaly in the geological past (According to Case 2 thermometer scenario of Lloyd et al., 2017). As such, the apparent $\mathrm{T} \Delta_{47}$ values lower than the environment temperatures indicate that the samples have only experienced partial equilibration at their peak burial temperatures. Note that this argument does not apply to samples from the GL3 well (southernmost sampling well, Gucheng uplift) (Fig. 10), which could have reached full equilibration.

Figure 10. Present-day burial temperatures versus carbonate clumped isotope temperatures $\left(\mathrm{T} \Delta_{47}\right)$. Error bars are $\pm 1 \mathrm{SE}$ for measured $\mathrm{T} \Delta_{47}$. Except for samples from GL3 well, most samples have T $\Delta_{47}$ lower than the present-day burial temperature.

Samples that have undergone partial solid state equilibration of their apparent $\mathrm{T} \Delta 47$ values must have experienced elevated burial temperature longer than those that only experienced onset partial solid-state reordering (under burial temperature of 80-120 ${ }^{\circ} \mathrm{C}$ for calcite over tens of millions of years; Passey and Henkes, 2014; Henkes et al., 2014; Stolper and Eiler, 2015) but cooler or shorter than the conditions that lead to full equilibration (under burial temperature above $175^{\circ} \mathrm{C}$ for millions of years or longer).

The paired exchange/diffusion model of Stolper and Eiler (2015) was applied to construct a thermal history model consistent with our observations. A comparison of model findings with the results of other published solid-state reordering models is discussed in detail in the following section. Our model assumes that the micrite samples from the Tabei and Shunbei areas formed by initial marine carbonate precipitation at a temperature of $25^{\circ} \mathrm{C}$ ( similar to surface seawater temperature estimates at low latitude Paleozoic conditions; Veizer and Prokoph, 2015; Jaffrés et al., 2007; Bergmann et al. 2018) at an age given by the U-Pb constraints on deposition (i.e. 477.7-471.8 Ma for the Yingshan Formation and of 471.8-458.4 Ma for the Yijianfang Formation; Fig. 9, 11). Other micrite samples that yielded U-Pb ages significantly younger than their depositional ages were assumed to have formed by recrystallization during burial diagenesis, and were assigned initial growth temperatures of $27.8 \square$ for micrite from ST1 well, $123 \square$ for micrite from SN4 well and $170.7 \square$ for micrite from GL3 well, based on their measured ages and linear interpolation in the thermal histories constrained by burial histories and basin thermal modeling (Fig. 11). The timing of precipitation/recrystallization for micrite from the SN5-2 well was inferred based on the burial history of SN4 well, on the basis of their close distance in location and similar petrographic and isotopic features, and are given $63 \square$ as recrystallization temperatures. The precipitation temperature of cements and veins is chosen according to previously published diagenetic sequences. Referring to the paragenetic history of the Tabei area (e.g. Jiao, 2017), Shunbei area (e.g. Jiao, 2017), Shunnan area (e.g. Lu et al., 2017) and Gulong area (e.g. Lu et al., 2018), the cements from the Shunbei and Shuntuo areas were precipitated during early

This article is protected by copyright. All rights reserved. 
diagenesis at depths less than $300 \mathrm{~m}-1000 \mathrm{~m}$, and the veins from the TP18 well, SHB2 well and GL3 well were precipitated at depths of 500-1000m, 2000m-3000m and $3000-4000 \mathrm{~m}$ respectively. When this information is combined with models of burial histories, the precipitation temperatures were given as: $40 \square$ for the cement sample from the SHB2 and ST1 wells, 30 $\square$ for the vein sample from the TP18 well, 80 $\square$ for the vein sample from the SHB2 well, and $150 \square$ for the vein samples from the GL3 well (Fig. 11).

Figure 11. Thermal history modeling results of clumped isotope temperatures under different thermal history scenarios using the paired exchange-diffusion model of Stolper and Eiler (2015). Measured clumped isotope temperatures (T $\left.\Delta_{47}\right)$ are plotted besides time $=0$. Three temperature-time paths with varying peak burial temperature in Permian were provided for each sample to find the best-fit thermal history scenario to measured $\mathrm{T} \Delta_{47}$. (a-f, $\mathrm{h}$ ) Thermal modeling results for micrite samples from different wells, with the precipitation timing of micrites constrained by in-situ U-Pb dating; (i1) Thermal modeling results for cements and veins from TP18, SHB2, ST1 and GL3 wells, with the initial constrained by paragenetic sequences. (g) Comparison between burial temperature, measured $\mathrm{T} \Delta_{47}$ and estimated peak burial temperature range. Error envelopes of modeling results are omitted for clarity. $\mathrm{T} \Delta_{47}$ are reported with $1 \mathrm{SE}$ of replicate analyses.

After precipitation, the calcite fabrics were then exposed to a temperature-time path of elevated burial temperatures for proscribed heating durations, which, when combined with prior experimental constraints on bond reordering kinetics, led to predicted changes in apparent $\mathrm{T} \Delta_{47}$ values due to solid-state $\mathrm{C}-\mathrm{O}$ bond reordering (black dotted line in Fig. 11). The differences in final modeled $\mathrm{T} \Delta 47$ using different thermal paths are small. The final modeled $\mathrm{T} \Delta 47$ for progressive heating, 'low $\mathrm{T}$ ' and 'intermediate T' scenarios only differ by $20 \square$ for some wells, such as TS301 and TP18 wells. Therefore, we conducted as many replicates as possible to minimize the standard errors of measured $\mathrm{T} \Delta 47$ and statistically distinguish these different scenarios (Table 1,2).

The results of this first round of forward models based on burial history constraints on temperature-time history lead to predicted clumped isotope apparent temperatures that are lower than measured values, especially for micrite samples, for all wells other than those from the Shunnan and Gulong areas. Although the measured T $\Delta_{47}$ values and those predicted by forward modeling of the "base case" scenarios are not significantly discrepant, we notice that even for the samples (micrite from TP18 well) for which $\mathrm{T} \Delta_{47}$ temperatures are the closest to base-case T-t paths $\left(76 \pm 3^{\circ} \mathrm{C}\right)$, the lower limits of measured $\mathrm{T} \Delta_{47}\left(73^{\circ} \mathrm{C}\right)$ is still higher than the modeled $\mathrm{T} \Delta_{47}(70)$ for basecase T-t path. That is, burial history constraints predict temperature-time histories with too low of peak burial temperatures to drive the required extents of resetting of the clumped isotope apparent temperatures. This finding suggests that peak burial temperatures for most of the studied wells were higher than one would infer from burial depths and from assumptions about the past geothermal gradient suggested in

This article is protected by copyright. All rights reserved. 
previous studies in this area. We hypothesize that this discrepancy is due to a thermal pulse starting during the Permian period. This hypothesis is suggested by two main points: (1) tectonic movement and magmatic activity were most intense during the Permian, as evidenced by basin-wide erosion and the occurrence of a Large Igneous Province (LIP) during that period (Fig. 4); This episode of uplift and magmatic activity could have led to thermal anomalies either because of significantly underestimated peak burial (i.e., the base model does not recognize a period of uplift and excess erosion) or because of excess heat flow associated with magmatism; and (2) Previous studies have recognized abrupt offsets of equivalent vitrinite reflectance $\left(\% \mathrm{R}_{\text {equ }}\right.$ ) profiles at the Permian-Triassic unconformity in the studied region, with $\mathrm{R}_{\text {equ }}$ abruptly decreasing to much lower values just above the unconformity (e.g. Wang et al. 2010; Li et al., 2010; Li et al., 2016). This implies that the Late Permian portion experienced much higher peak temperatures than the overlying portion.

Two tectono-thermal events have been suggested to account for the possible thermal pulse in the studied region: A period of uplift and erosion caused by the collision with the central Tianshan arc during Late-Permian (Zhang et al., 2013; Lin et al., 2012; Liu et al., 2015; He et al., 2016), or the Permian basin-scale magmatic flareup during $292 \mathrm{Ma}-269 \mathrm{Ma}$, induced by mantle plume upwelling around $300 \mathrm{Ma}$ (Li et al., 2011; Yang et al., 2013; Li et al., 2014; Wei et al., 2014; Xu et al., 2014; Zhang et al., 2016) (Fig. 4). We explored these two hypotheses by fitting variant temperature-time models to our clumped isotope data set.

All of the following models include a pulse of excess heat (i.e., temperatures above those predicted by the base thermal model informed by burial histories), initiating at $290 \mathrm{Ma}$, peaking at 280Ma and cooling back to ambient (i.e., base-model) temperatures by $270 \mathrm{Ma}$ (Fig. 11). We developed three new temperature-time scenarios for each studied well, termed as 'low T', 'intermediate T' and 'high T' scenarios, named after the amplitude of the pulse of excess temperature each experienced (Fig. 11). For these three scenarios, the duration of thermal pulse stays the same, while 10-20 $\square$ excessive heat was added to the peak burial temperature successively from 'low T' to 'intermediate T' and to 'high T' scenarios (Fig. 10). For purpose of inter-calibration, we compared the best-fit temperature-time scenarios constrained by different calcite fabrics from a single well (e.g. micrite, cements and veins from the SHB2 well), in order to give best constraints on peak burial temperature (Fig. 11). As illustrated in Fig. 11, most measured apparent $\mathrm{T} \Delta_{47}$ fit best with the results of 'low T' scenarios. Specifically, for the Tabei area, the apparent T $\Delta_{47}$ of micrite from the TS301 and TP18 wells and vein calcite from the TP18 well (73 $\pm 1 \square, 76 \pm 3 \square$ and $76 \pm 7 \square$, respectively) fall within the range between the 'low$\mathrm{T}$ ' and 'intermediate- $\mathrm{T}$ ' scenarios, indicating the peak burial temperature resides in a range of $160^{\circ} \mathrm{C}-180^{\circ} \mathrm{C}$. For the Shunbei area, the apparent $\mathrm{T} \Delta 47$ of micrite from the SHB2 well is $92 \pm 1^{\circ} \mathrm{C}$, corresponding to a peak burial temperature range between the 'low- $\mathrm{T}$ ' and 'intermediate-T' modeling results (i.e. a peak temperature range of $170^{\circ} \mathrm{C}-180^{\circ} \mathrm{C}$ ), which is consistent with the peak burial temperature range constrained by calcite cements and calcite veins from the SHB2 well. Similarly, the comparison of model results and measured samples from the ST1 well imply a peak burial

This article is protected by copyright. All rights reserved. 
temperature in the range of $180^{\circ} \mathrm{C}-190^{\circ} \mathrm{C}$. The clumped isotope apparent temperatures of micrite from the Shunan and Gulong areas are consistent with the base thermal model (i.e., based on burial histories with no tectonic or magmatic thermal pulse), suggesting the present-day temperature is the peak burial temperature. For samples from the Shunnan and Gulong areas, the relatively large uncertainties (up to $\pm 24 \mathrm{Ma}$ for SN4 sample, and \pm 8 .8Ma for GL3 sample) $\mathrm{U}-\mathrm{Pb}$ ages would cause their extrapolated initial temperatures vary by tens of degree Celsius. Therefore, we conducted sensitivity modeling tests using their youngest ages (lower limit of U-Pb age) and oldest ages (upper limit of U-Pb ages) as initial temperatures (Fig. S16-S18). The results show that all final modeled $\mathrm{T} \Delta 47$ results equals or higher than measured $\mathrm{T} \Delta_{47}$, suggesting that thermal pulse did not occur in these areas, consistent with modeling results using the mean $\mathrm{U}-\mathrm{Pb}$ ages.

We independently calculated the thermal histories required to explain the equivalent vitrinite reflectance ( $\% \mathrm{R}_{\text {equ }}$ ) observed in samples related to those we have studied. These calculations were made using the Easy\%Ro kinetic model of Sweeney and Burnham (1990), using the same assumptions about the Temperature-time scenarios (Fig. 12). Easy\%Ro forward models of \% $\mathrm{R}_{\text {equ }}$ suggest peak burial temperature ranges during the Permian that are similar to or slightly higher than those implied by our models of carbonate clumped isotope composition; specifically, this approach results in peak temperature estimates of $190 \square-200 \square$ for the TP18 well, 180$190 \square$ for the SHB2 well, 180-190 $\square$ for the ST1 well, and can explain the measured $\% \mathrm{R}_{\text {equ }}$ for the SH4 well with the base-case thermal model (i.e., without a thermal pulse in the Permian). Thus, the constraints from $\% \mathrm{R}_{\text {equ }}$ are generally consistent with our conclusions based on carbonate clumped isotope compositions.

By combining the constraints from carbonate solid-state reordering models and Easy\%Ro models, we suggest peak burial temperatures of 160-200 $\square$ in the Tabei area, 170-190 $\square$ in the Shunbei area and 180-190 $\square$ in the Shuntuo area (Fig. 11, 12). By contrast, for the Shunnan and Gulong areas, both solid-state reordering and Easy\%Ro modeling results indicated the progressive heating base-case thermal scenario was the best fit, and the peak burial temperatures for these areas are the present-day burial temperatures (Fig. 11, 12).

Figure 12. Thermal history modeling results of equivalent Ro ( $\left.\mathrm{R}_{\text {equ }}\right)$ under different thermal history scenarios using the Easy\%Ro kinetic model of Sweeney and Burnham (1990). Measured equivalent Ro $\left(\mathrm{R}_{\text {equ }}\right)$ are plotted besides time $=0$. Several temperature-time paths with varying peak burial temperature in Permian were provided for each sample to find the best-fit thermal history scenario to measured $\mathrm{R}_{\text {equ. }}$

Several sources of uncertainties could give rise to systematic errors in these model estimates: (1) Uncertainty on the precise timing and duration of the peak burial temperature. Due to the lack of supporting data on the exact timing and duration of tectonic and/or magmatic drivers of the hypothesized thermal pulse, it is hard to constrain the timing and duration of the thermal pulse(2) Uncertainty on the details of

This article is protected by copyright. All rights reserved. 
the T-t paths. It is possible that the variation of temperature with time, especially the proposed thermal pulse, was more complex than modeled; (3)Uncertainty on the universal $\Delta 47$-temperature calibration; (4) Uncertainty on the Arrhenius parameters for the solid-state reordering model. Our models of solid-state clumped isotope reordering kinetics are based on high-temperature laboratory heating experiments, and it is possible that extrapolation to the temperature ranges of natural settings leads to larger systematic errors. Hence, we should admit that many of these uncertainties are substantial and once all uncertainties considered, the results of calcite $\Delta_{47}$ would not be effective in verifying the thermal pulse, i.e., the measured and modeled $\mathrm{T} \Delta_{47}$ might overlap within $2 \sigma$ uncertainty.

We also cannot ignore the fact the Ordovician carbonate samples are buried so deeply that the modern ambient temperatures of these fabrics are only $10-40{ }^{\circ} \mathrm{C}$ lower than the peak burial temperatures during the Permian thermal pulse event, and such comparatively small differences in peak temperature, especially in the window of $120-180{ }^{\circ} \mathrm{C}$ where the rates of calcite $\Delta_{47}$ reordering are quite uncertain (Stolper and Eiler, 2015), are making it challenging to constrain thermal anomaly events with confidence using calcite $\Delta_{47}$ reordering models alone. Therefore, we stress that it is the integration of multiple lines of evidences that confirms the existence of thermal pulse. And we call for cautions when using carbonate $\Delta_{47}$ in thermal history reconstruction.

In addition, it is still worth noting that due to material limitation, the sampling strategy in this study is not very ideal for thermal history reconstruction, and we propose that a better way to test the existence of thermal anomaly would be to examine carbonate samples from a range of depths (at least $>1 \mathrm{~km}$ apart) in the same cores, and if possible, of different mineralogies (e.g., calcite, dolomite and apatite). Comparing relatively larger differences in $\mathrm{T} \Delta 47$ of carbonate samples collected from different depths would be more statistically robust when using $\Delta_{47}$ solid-state reordering models. In future work, we will try to find more suitable wells with adequate cores to conduct that work.

\subsection{Tectono-thermal interpretations of the high thermal anomaly}

In this section we explore the thermal effects of two putative causes of the Permian thermal pulse - intense burial followed by uplift and erosion, or, alternatively, magmatism; we evaluate the contributions of each of these processes separately, as end-member scenarios, but note that it is imaginable both processes coincided in time and combined to create the observed temperature-time history.

We simulated the thickness of sediment eroded during the Permian using BasinMod modeling software; modeled sediment thicknesses were adjusted until the model predicted peak burial temperatures that match those reconstructed by geochemical proxies. This approach assumes that intense burial followed by uplift was the main cause for thermal anomalies. The resulting erosion thickness of the 4 wells ranges from $3240 \mathrm{~m}$ to $6490 \mathrm{~m}$ (Table 3), with the thickest values in the TS301 well and the thinnest in the ST1 well. This range of model-computed eroded sediment thicknesses greatly exceeds the previously estimated maximum erosion of $\sim 2000 \mathrm{~m}$ in

This article is protected by copyright. All rights reserved. 
Tabei uplift during Permian erosion event, independently constrained by geophysical observations and numerical simulation (Qi and Liu, 1999; Zhang et al., 2000; Li et al., 2011; Lin et al., 2012; Liu et al., 2015). In addition, it has been suggested previously that during the Late-Permian erosion event, erosion intensity decreased southward from the Tabei area to Shunnan area, and that the Shuntuoguole uplift was built upon a subsidized depression with only weak uplift and erosion (e.g. Lin et al., 2012; Liu et al., 2015). The removal of at least $3000 \mathrm{~m}$ of sediment regionally, as required by our attempts to model the thermal anomaly, is not compatible with this independent estimate of the distribution of uplift and erosion.

Next, we examined a magmatic origin for the thermal pulse, induced either by conductive heat flow or basin-scale hydrothermal convection. As a first step in this evaluation, we calculated the maximum geothermal gradients that are implied by the geochemical temperature reconstructions of each well at the time of its peak burial temperature.

Geothermal gradients for boreholes are usually calculated by least-squares fitting using continuous temperature logging data. As we only reconstruct the paleotemperature of Mid-Late Ordovician strata, we used the thermal gradient calculation equation introduced by Qiu et al., (2012) and Liu et al., (2016). The calculated thermal gradient $\mathrm{G}$ (in ${ }^{\circ} \mathrm{C} / \mathrm{km}$ ) is an average value over the depth interval from the studied strata at depth $\mathrm{Z}(\mathrm{km})$ and constant burial temperature $\mathrm{T}(\square)$ :

$\mathrm{G}=\mathrm{T}-\mathrm{T} 0 /(\mathrm{Z}-\mathrm{Z} 0)$

Where $\mathrm{T} 0$ and $\mathrm{Z} 0$ are constant burial temperature $\left(12{ }^{\circ} \mathrm{C}\right.$ in the Tarim Basin, Qiu et al., 2012 and Liu et al., 2016) and the corresponding burial depth $(0.02 \mathrm{~km}$ in the Tarim Basin).

As shown in Table 3, the estimated maximum geothermal gradients vary from $26.6 \square / \mathrm{km}$ to $69.3 \square / \mathrm{km}$ and exhibit a southward decreasing trend (Fig. 13). The Tarim Basin has been characterized by low heat flow and low geothermal gradients since the Ordovician (Feng et al., 2009; Liu et al., 2006, 2016). The geothermal gradients reconstructed here exceed the estimated background geothermal gradients during the Carboniferous-Permian ( $30 \square / \mathrm{km}$, Qiu et al., 2012) and the present-day geothermal gradients in the Tarim Basin $(\sim 15 \square / \mathrm{km}-30 \square / \mathrm{km}$, with an average of $20.7 \pm 2.9 \square / \mathrm{km}$, Liu et al., 2016) (Fig. 13). Thus, our temperature reconstructions call for heat input to most of the studied sections during the Permian.

Figure 13. Simulated geothermal gradients during the Permian thermal pulse. Shaded area represents the present-day geothermal gradients reported in the Tarim Basin.

Erupted flood basalts and intruded dikes could only heat surrounding country rock to a distance of several tens of meters, and are not capable of creating a regional thermal anomaly of the scale and magnitude required by our observations (Galushkin, 1997; Stewart et al., 2005; Finnegan et al., 2011; Nabelek et al., 2012; Liu et al., 2017). Emplaced plutons could heat overlying sediments to distances of up to $\sim 4 \mathrm{~km}$ to temperature as high as 200 $\square$ (Cui et al., 2001; Nabelek et al., 2012; Lloyd et al., 2017), but it seems implausible to us that the typical sizes of plutonic bodies could

This article is protected by copyright. All rights reserved. 
cover an area as large as the region studied. A mantle plume, which has been previously suggested as the origin of the large igneous province in the Tarim Basin (Yang et al., 2013; Li et al., 2014; Xu et al., 2014), could be characterized by a wide lateral expanse (several 100's km), and thus could affect heat flow over a large area (Campbell and Davies 2006; Burov et al. 2007; Campbell, 2007; Edwards and Blackburn, 2019). Present-day surface heat flow in some areas affected by mantle plumes reaches to $\geq 100 \mathrm{~mW} / \mathrm{m}^{2}$ (Gouveia et al., 2018), and can thus be regarded as a heat source that could plausibly explain our reconstructed thermal histories. In this scenario, hydrothermal fluid convection or conductive heat would have been required to transfer heat from the hot mantle plume head to the overlying sedimentary section.

It is previously recognized that the nearby Sichuan Basin, which has a tectonic and magmatic history similar to the Tarim Basin, experienced Permian mantle plume activity. Geothermal studies in the Sichuan basin have revealed a high thermal anomaly induced by a mantle plume during the Permian, generating geothermal gradients up to $>40 \square / \mathrm{km}$, with gradients reaching their highest values above the center of the mantle plume and decreasing away from the center (Zhu et al., 2016, 2018; Jiang et al., 2018). The geothermal gradients we calculate for the Permian Tarim Basin closely resemble those in the Sichuan Basin. The spatial pattern of peak burial temperatures and geothermal gradients correspond well to the distribution of Tarim Large Igneous Province (TLIP) (Fig. 13), as only areas containing igneous rock in Permian strata were heated (Fig. 1). In addition, the peak geothermal gradient we reconstruct is located near the Tabei area - consistent with previous suggestion that a mantle plume was emplaced with its center residing around the Tabei area (Li et al., 2014, Xu et al., 2014). These lines of evidence all support the hypothesis of a thermal pulse resulting from mantle plume heating of the Tarim Basin during the Permian.

In summary, the hypothesis that magmatic activity generated a thermal pulse during the late Permian appears more supported than the scenario involving burial followed by erosion. The existence of this putative thermal event significantly impacts our current understanding of hydrocarbon generation and migration history in the Tarim Basin, and raises questions about whether dry gas was generated when source rock was exposed to such high temperatures, and where it migrated or leaked. Future work is required to confirm this abnormal high-temperature thermal pulse and to illustrate its influence on source rock and hydrocarbon generation.

\subsection{Implications for parameterization of bond-reordering kinematic models}

We conducted a sensitivity test of the impacts of different solid-state reordering kinetics on our reconstructions of peak burial temperatures; specifically, we varied the kinetic parameters derived from previous studies by $\pm 1 \sigma$ uncertainty from their mean values and explored the implications of these changes for observed clumped isotope temperatures in models that varied the peak burial temperature between $160 \square$ and $190 \square$. Following the procedural of Lloyd et al., (2017), the activation energy ( $\left.E_{a}\right)$ and natural $\log$ of the frequency factor $\left(\ln \mathrm{K}_{0}\right)$ were co-varied in the same proportion of uncertainty, assuming their possible values were well correlated. Note that for the paired exchange/diffusion model of Stolper and Eiler (2015), only the kinetic

This article is protected by copyright. All rights reserved. 
parameters of the singleton diffusion step were varied, as this step dominates the kinetics of partial resetting during heating.

As shown in Fig. 14, while roughly all the mean values of kinetic parameters for the Stolper and Eiler (2015) model fit the measured $\mathrm{T} \Delta_{47}$ results, only the upper range of the $0.5-1 \sigma$ uncertainty extrapolation (i.e. higher $\mathrm{E}_{\mathrm{a}}$ and $\ln \mathrm{K}_{0}$ resulting in slower rate constants) of the Passey and Henkes (2012) kinetic parameters match the measured $\mathrm{T} \Delta_{47}$ result. That is, when applying the Passey and Henkes (2012) model, full equilibration would occur for most thermal evolution scenarios discussed above, and would predict much higher $\mathrm{T} \Delta 47$ than measured (Fig. 14).

Figure 14. Comparison between the results of paired exchange-diffusion model of Stolper and Eiler (2015) (Left panel, a, b, c, d) and the first-order approximation model of Passey and Henkes (2012) (right panel, e, f, g, h) during different thermal history scenarios of studied areas. Kinetic parameters were varied by up to $\pm 1 \sigma$ uncertainty from their mean values test the sensitivity of different solid-state reordering models to rate constants and peak burial temperature (b, c).

This finding suggests that when extrapolated to burial temperatures in the range typical of sedimentary basins, the Stolper and Eiler (2015) model best reproduces $\mathrm{T} \Delta_{47}$ values of natural samples, whereas the Passey and Henkes (2012) model has higher mean rate constants and predicts higher $\mathrm{T} \Delta_{47}$ values than are observed. Contrary to our finding, carbonate $\mathrm{T} \Delta_{47}$ reordering models in Notch Peak contact metamorphic aureole in Utah by Lloyd et al., (2017) reported slower rate constants for the Stolper and Eiler (2015) model than for the Passey and Henkes (2012) model. We suspect that the differences in kinetic parameters reported in these studies for the two reordering models are related to the detailed burial/heating histories and exact thermal evolution paths used during reordering modelling runs. Specifically, our studied intervals continued deep burial with increasing burial temperature till the present day, while those examined by Lloyd et al. (2017) are characterized by late-stage exhumation with a final cooling step to surface temperatures, thus the response of modelling-predicted clumped isotope values to kinetic parameters could be different between heating and cooling scenarios for the two solid-state reordering models.

\section{Conclusions}

We employed clumped isotope and solid-state reordering models to reconstruct the thermal histories of deeply buried Ordovician carbonate intervals in the Tarim Basin. The starting anchor for thermal history modelling were constrained for micrite by insitu calcite $\mathrm{U}-\mathrm{Pb}$ dating, and for cements and veins by referring to paragenetic sequences. 20 samples from seven representative wells were measured for clumped isotope, covering a vast area from the Tabei uplift to Shuntuoguole uplift. Except for samples from the Shunan and Gulong areas, all other samples have not fully equilibrated at peak burial temperatures and can be used for thermal history reconstruction. Combined with the Easy\%Ro modeling results of $R_{\text {equ }}$, the reconstructed thermal histories reveal a short-lived Permian thermal pulse in Tabei,

This article is protected by copyright. All rights reserved. 
Shunbei and Shuntuo areas during Permian, with the peak burial temperature residing in the ranges of 160-200 $\square, 170 \square-190 \square, 180 \square-190 \square$ and $170 \square-190 \square$, respectively. Assuming the Late-Permian regional erosion as the sole cause for the Permian thermal pulse, the geothermally simulated eroded thickness of the 6 wells ranges from $3120 \mathrm{~m}$ to $6490 \mathrm{~m}$ greatly exceeding previously estimated erosion intensity for this period. By contrast, the spatial patterns of peak burial temperature and geothermal gradients closely correspond to the distribution of Large Igneous Province and proposed mantle plume emplacement model, and suggest that the thermal pulse resulting from mantle plume activity is a more reasonable scenario for interpreting the reconstructed thermal histories. The tentative use of carbonate $\Delta_{47}$, in-situ U-Pb dating and solid-state reordering model in this study indicates that the integration of these techniques holds the potential to be developed as a novel thermochronological method suitable for reconstructing the thermal histories of deeply-buried carbonate intervals.

This article is protected by copyright. All rights reserved. 


\section{Acknowledgments}

We thank the SINOPEC Northwest Company and individuals who contributed samples and information for this work. This study was funded by Science funding for Innovative Research Groups of the National Natural Science Foundation of China (Grant No. 41821002), Strategic Priority Research Program of the Chinese Academy of Sciences (Grant No. XDA14010305), and AAPG Grants-In-Aid program. F. C would like to acknowledge the scholarship from China Scholarship Council (CSC). We would like to thank Nami Kitchen for her assistance with clumped isotope measurements, Sang Chen and Uri Ryb for their instruction in calcite solid-state reordering modeling, and Xavier Mangenot and Miquela Ingalls for helpful discussions. This manuscript greatly benefits from the review of associate editor Stephen Parman, Catherine Mottram and an anonymous reviewer. Our calcite U-Pb data in this study are available from Dataset $\mathrm{S} 1$ in the supporting information and the Geochron database (https://www.geochron.org/). The raw clumped isotope data are available from Dataset $\mathrm{S} 2$.

This article is protected by copyright. All rights reserved. 


\section{References}

Bartolini, A., Baumgartner, P. O., Guex, J. (1999), Middle and Late Jurassic radiolarian palaeoecology versus carbon-isotope stratigraphy. Palaeogeography, Palaeoclimatology, Palaeoecology, 145(1-3), 43-60.

Bennett, C. E., Williams, M., Leng, M. J., Lee, M. R., Bonifacie, M., Calmels, D., ... Munnecke, A. (2018), Oxygen isotope analysis of the eyes of pelagic trilobites: Testing the application of sea temperature proxies for the Ordovician. Gondwana Research, 57, 157-169.

Bergmann, K. D., Finnegan, S., Creel, R., Eiler, J. M., Hughes, N. C., Popov, L. E., Fischer, W. W. (2018), A paired apatite and calcite clumped isotope thermometry approach to estimating Cambro-Ordovician seawater temperatures and isotopic composition. Geochimica et Cosmochimica Acta, 224, 18-41.

Bonifacie, M., Calmels, D., Eiler, J. M., Horita, J., Chaduteau, C., Vasconcelos, C., ... \& Bourrand, J. J. (2017), Calibration of the dolomite clumped isotope thermometer from 25 to $350 \mathrm{C}$, and implications for a universal calibration for all ( $\mathrm{Ca}, \mathrm{Mg}, \mathrm{Fe}$ ) $\mathrm{CO}_{3}$ carbonates. Geochimica et Cosmochimica Acta, 200, 255-279.

Burov, E., Guillou-Frottier, L., d'Acremont, E., Le Pourhiet, L., Cloetingh, S. A. P. L., (2007), Plume head-lithosphere interactions near intra-continental plate boundaries. Tectonophysics, 434(1-4), 15-38.

Cai, X.Y., Li, Y. (2008), Ordovician lithofacies and stratigraphic lacunae in the southern part of the Central Tarim, Xinjiang. Journal of Stratigraphy, 32 (4), 353-362 (in Chinese with English abstract).

Came, R. E., Eiler, J. M., Veizer, J., Azmy, K., Brand, U., Weidman, C. R. (2007), Coupling of surface temperatures and atmospheric $\mathrm{CO}_{2}$ concentrations during the Palaeozoic era. Nature, 449(7159), 198.

Campbell, I. H. (2007), Testing the plume theory. Chemical Geology, 241(3-4), 153176.

Campbell, I. H., Davies, G. F. (2006), Do mantle plumes exist? Episodes, 29(3), 162.

Chen, Z. Q., Shi, G. R. (2003), Late Paleozoic depositional history of the Tarim basin, northwest China: An integration of biostratigraphic and lithostratigraphic constraints. AAPG Bulletin, 87(8), 1323-1354.

Coimbra, R., Immenhauser, A., Olóriz, F. (2009), Matrix micrite $\delta^{13} \mathrm{C}$ and $\delta^{18} \mathrm{O}$ reveals synsedimentary marine lithification in Upper Jurassic Ammonitico Rosso limestones (Betic Cordillera, SE Spain). Sedimentary Geology, 219(1-4), 332348.

Cui, X., Nabelek, P. I., Liu, M. (2001), Heat and fluid flow in contact metamorphic aureoles with layered and transient permeability, with application to the Notch Peak aureole, Utah. Journal of Geophysical Research: Solid Earth, 106(B4), 6477-6491.

This article is protected by copyright. All rights reserved. 
Cummins, R. C., Finnegan, S., Fike, D. A., Eiler, J. M., Fischer, W. W. (2014), Carbonate clumped isotope constraints on Silurian ocean temperature and seawater $\delta^{18} \mathrm{O}$. Geochimica et Cosmochimica Acta, 140, 241-258.

Daeron, M., Guo, W., Eiler, J., Genty, D., Blamart, D., Boch, R., ... \& Zanchetta, G. (2011), ${ }^{13} \mathrm{C}^{18} \mathrm{O}$ clumping in speleothems: Observations from natural caves and precipitation experiments. Geochimica et Cosmochimica Acta, 75(12), 33033317.

Deng, S., Li, H.L., Zhang, Z.P., Zhang, J.B. and Yang, X. (2019), Structural characterization of intracratonic strike-slip faults in the central Tarim Basin. AAPG Bulletin. 103, 109-137.

Dennis, K. J., Affek, H. P., Passey, B. H., Schrag, D. P., Eiler, J. M. (2011), Defining an absolute reference frame for 'clumped' isotope studies of $\mathrm{CO} 2$. Geochimica et Cosmochimica Acta, 75(22), 7117-7131.

Drost, K., Chew, D., Petrus, J. A., Scholze, F., Woodhead, J. D., Schneider, J. W., \& Harper, D. A. (2018)), An Image Mapping Approach to U $\square$ Pb LA $\square$ ICP $\square$ MS Carbonate Dating and Applications to Direct Dating of Carbonate Sedimentation. Geochemistry, Geophysics, Geosystems, 19(12), 4631-4648.

Edwards, G. H., and Blackburn, T. (2019), Detecting the extent of ca. $1.1 \mathrm{Ga}$ Midcontinent Rift plume heating using $\mathrm{U}-\mathrm{Pb}$ thermochronology of the lower crust. Geology, 46 (10), 911-914.

Eiler, J. M. (2007), "Clumped-isotope" geochemistry-The study of naturallyoccurring, multiply-substituted isotopologues. Earth and planetary science letters, 262(3-4), 309-327.

Eiler, J. M. (2011), Paleoclimate reconstruction using carbonate clumped isotope thermometry. Quaternary Science Reviews, 30(25-26), 3575-3588.

Feng, C. G., Liu, S. W., Wang, L. S., LI, C. (2009), Present $\square$ day geothermal regime in Tarim basin, northwest China. Chinese Journal of Geophysics, 52(6), 12371250.

Ferry, J. M., Passey, B. H., Vasconcelos, C., Eiler, J. M. (2011), Formation of dolomite at $40-80^{\circ} \mathrm{C}$ in the Latemar carbonate buildup, Dolomites, Italy, from clumped isotope thermometry. Geology, 39(6), 571-574.

Finnegan, S., Bergmann, K., Eiler, J. M., Jones, D. S., Fike, D. A., Eisenman, I., ... Fischer, W. W. (2011), The magnitude and duration of Late Ordovician-Early Silurian glaciation. Science, 331(6019), 903-906.

Gallagher, T. M., Sheldon, N. D., Mauk, J. L., Petersen, S. V., Gueneli, N., Brocks, J. J. (2017), Constraining the thermal history of the North American midcontinent rift system using carbonate clumped isotopes and organic thermal maturity indices. Precambrian Research, 294, 53-66.

Galushkin, Y. I. (1997), Thermal effects of igneous intrusions on maturity of organic matter: A possible mechanism of intrusion. Organic Geochemistry, 26(11-12), 
645-658.

Gao, G., Land, L. S. (1991), Geochemistry of Cambro-Ordovician Arbuckle limestone, Oklahoma: Implications for diagenetic $\delta^{18} \mathrm{O}$ alteration and secular $\delta^{13} \mathrm{C}$ and ${ }^{87} \mathrm{Sr} /{ }^{86} \mathrm{Sr}$ variation. Geochimica et Cosmochimica Acta, 55(10), 29112920.

Gao, Y., Zhang, X., Zhang, G., Chen, K., Shen, Y. (2018), Ediacaran negative Cisotopic excursions associated with phosphogenic events: Evidence from South China. Precambrian Research, 307, 218-228.

Ghosh, P., Adkins, J., Affek, H., Balta, B., Guo, W., Schauble, E. A., ... \& Eiler, J. M. (2006), 13C-18O bonds in carbonate minerals: a new kind of paleothermometer. Geochimica et Cosmochimica Acta, 70(6), 1439-1456.

Gleadow, A. J. W., Duddy, I. R., Green, P. F., Lovering, J. F. (1986), Confined fission track lengths in apatite: a diagnostic tool for thermal history analysis. Contributions to Mineralogy and Petrology, 94(4), 405-415.

Godeau, N., Deschamps, P., Guihou, A., Leonide, P., Tendil, A., Gerdes, A., Hamelin, N. and Girard, J. (2018) U-Pb dating of calcite cement and diagenetic history in microporous carbonate reservoirs: Case of the Urgonian Limestone, France. Geology, 46 (3), 247-250.

Gouveia, D., S. V., Besse, J., de Lamotte, D. F., Greff-Lefftz, M., Lescanne, M., Gueydan, F., Leparmentier, F. (2018), Evidence of hotspot paths below Arabia and the Horn of Africa and consequences on the Red Sea opening. Earth and Planetary Science Letters, 487, 210-220.

Grossman, E.L. (2012), Oxygen isotope stratigraphy. In: Gradstein, F.M., et al. (Eds.) The Geologic Time Scale 2012. Elsevier, Amsterdam, 195-220.

Guido, A., Mastandrea, A., Stefani, M., Russo, F. (2016), Role of autochthonous versus detrital micrite in depositional geometries of Middle Triassic carbonate platform systems. Bulletin, 128(5-6), 989-999.

He, B.Z., Xu, Z.Q.， Jiao, C.L. ， Li H.B. and Cai Z.H. （2011), Tectonic unconformities and their forming: Implication for hydrocarbon accumulations in Tarim basin. Acta Petrologica Sinica, 27(1), 253-265.

He, B., Jiao, C., Xu, Z., Cai, Z., Zhang, J., Liu, S., ... Yu, Z. (2016), The paleotectonic and paleogeography reconstructions of the Tarim Basin and its adjacent areas (NW China) during the late Early and Middle Paleozoic. Gondwana Research, 30, 191-206.

Henkes, G. A., Passey, B. H., Grossman, E. L., Shenton, B. J., Pérez-Huerta, A., Yancey, T. E. (2014), Temperature limits for preservation of primary calcite clumped isotope paleotemperatures. Geochimica et cosmochimica acta, 139, 362-382.

Henkes, G. A., Passey, B. H., Grossman, E. L., Shenton, B. J., Yancey, T. E., PérezHuerta, A. (2018), Temperature evolution and the oxygen isotope composition

This article is protected by copyright. All rights reserved. 
of Phanerozoic oceans from carbonate clumped isotope thermometry. Earth and Planetary Science Letters, 490, 40-50.

Henkes, G. A., Passey, B. H., Wanamaker Jr, A. D., Grossman, E. L., Ambrose Jr, W. G., Carroll, M. L. (2013), Carbonate clumped isotope compositions of modern marine mollusk and brachiopod shells. Geochimica et Cosmochimica Acta, 106, 307-325.

Hellwig, A., Voigt, S., Mulch, A., Frisch, K., Bartenstein, A., Pross, J., Gerdes, A.\& Voigt, T. (2018). Late Oligocene to early Miocene humidity change recorded in terrestrial sequences in the Ili Basin (south - eastern Kazakhstan, Central Asia). Sedimentology, 65(2), 517-539.

Holdsworth, R.E., McCaffrey, K.J.W., Dempsey, E., Roberts, N.M.W., Hardman, K. Morton, A. Feely, M., Hunt, J., Conway, A., and Robertson, A. (2019a), Natural fracture propping and earthquake-induced oil migration in fractured basement reservoirs. Geology, 47, 700-704.

Holdsworth, R. E., Trice, R., Hardman, K., McCaffrey, K. J. W., Morton, A., Frei, D., Dempsey, E., Bird, A. \& Rogers, S. (2019b). The nature and age of basement host rocks and fissure fills in the Lancaster field fractured reservoir, West of Shetland. Journal of the Geological Society. 177(5):1057.

Huang, T.Z. (2014), Structural interpretation and petroleum exploration targets in northern slope of middle Tarim Basin. Petroleum Geology \& Experiment, 36(3), 257-267 (in Chinese with English abstract).

Huntington, K. W., Budd, D. A., Wernicke, B. P., Eiler, J. M. (2011), Use of clumped-isotope thermometry to constrain the crystallization temperature of diagenetic calcite. Journal of Sedimentary Research, 81(9), 656-669.

Huntington, K. W., Lechler, A. R. (2015), Carbonate clumped isotope thermometry in continental tectonics. Tectonophysics, 647, 1-20.

Ingalls, M. (2019), Reconstructing carbonate alteration histories in orogenic sedimentary basins: Xigaze forearc, southern Tibet. Geochimica et Cosmochimica Acta, 251, 284-300.

Jaffrés, J. B., Shields, G. A., Wallmann, K. (2007), The oxygen isotope evolution of seawater: A critical review of a long-standing controversy and an improved geological water cycle model for the past 3.4 billion years. Earth-Science Reviews, 83(1-2), 83-122.

Jacob, H. (1989), Classification, structure, genesis and practical importance of natural solid bitumen. International Journal of Coal Geology, 11, 65-79.

Jia, C. Z., Wei, G. Q., Yao, H. J., Li, L. C. (1995), Tectonic evolution and regional structural geology: Book series on petroleum exploration in the Tarim Basin (in Chinese with English Abstract). Beijing, Petroleum Industry Press, 252 P.

Jia, C. (1997), Tectonic characteristics and petroleum, Tarim basin, China (in Chinese): Beijing, Petroleum Industry Press, 295 P. 
Jia, C., Wei, G. (2002), Structural characteristics and petroliferous features of Tarim Basin. Chinese Science Bulletin, 47(1), 1-11.

Jiang, L., Cai, C., Worden, R. H., Crowley, S. F., Jia, L., Zhang, K., Duncan, I. J. (2016), Multiphase dolomitization of deeply buried Cambrian petroleum reservoirs, Tarim Basin, north $\square$ west China. Sedimentology, 63(7), 2130-2157.

Jiang, Q., Qiu, N., Zhu, C. (2018), Heat flow study of the Emeishan large igneous province region: Implications for the geodynamics of the Emeishan mantle plume. Tectonophysics, 724, 11-27.

Jiao, C. (2017), The Genesis and prediction of the Middle and Lower Ordovician reservoirs in the Shunbei and adjacent areas of Tarim Basin. Internal Report of SINOPEC Research Company.

Jin, Z. J., Zhang, Y. W., Chen, S. P. (2005), The tectonic sedimentary process in the Tarim Basin: Sciences in China, 35, 530-539.

Joachimski, M. M., Van Geldern, R., Breisig, S., Buggisch, W., Day, J. (2004), Oxygen isotope evolution of biogenic calcite and apatite during the Middle and Late Devonian. International Journal of Earth Sciences, 93(4), 542-553.

Kasemann, S. A., Hawkesworth, C. J., Prave, A. R., Fallick, A. E., Pearson, P. N. (2005), Boron and calcium isotope composition in Neoproterozoic carbonate rocks from Namibia: evidence for extreme environmental change. Earth and Planetary Science Letters, 231(1-2), 73-86.

Land, L. S., Lynch, F. L. (1996), $\delta^{18}$ O values of mudrocks: more evidence for an 180-buffered ocean. Geochimica et Cosmochimica Acta, 60(17), 3347-3352.

Lawson, M., Shenton, B. J., Stolper, D. A., Eiler, J. M., Rasbury, E. T., Becker, T. P., ... \& Gray, G. G. (2018), Deciphering the diagenetic history of the El Abra Formation of eastern Mexico using reordered clumped isotope temperatures and U-Pb dating. GSA Bulletin, 130(3-4), 617-629.

Lacroix, B., Niemi, N. A. (2019), Investigating the effect of burial histories on the clumped isotope thermometer: An example from the Green River and Washakie Basins, Wyoming. Geochimica et Cosmochimica Acta, 247, 40-58.

Li, D. S., Liang, D. G., Jian, C. Z., Wang, G., Wu, Q. Z., He, D. F. (1996), Hydrocarbon accumulations in the Tarim basin, China. AAPG Bulletin, 80(10), 1587-1603.

Li, D., Yang, S., Chen, H., Cheng, X., Li, K., Jin, X., ... \& Zou, S. (2014), Late Carboniferous crustal uplift of the Tarim plate and its constraints on the evolution of the Early Permian Tarim Large Igneous Province. Lithos, 204, 3646.

Li, J. W., Li, Z., Qiu, N. S., Zuo, Y. H., Yu, J. B., Liu, J. Q. (2016), CarboniferousPermian abnormal thermal evolution of the Tarim basin and its implication for deep structure and magmatic activity. Chinese Journal of Geophysics, 59(9), 3318-3329 (in Chinese with English abstract).

This article is protected by copyright. All rights reserved. 
Li, Q., Parrish, R.R., Horstwood, M.S., and McArthur, J.M. (2014), U-Pb dating of cements in Mesozoic ammonites. Chemical Geology, 376, 76-83.

Li, M., Wang, T., Chen, J., He, F., Yun, L., Akbar, S., Zhang, W. (2010), Paleo-heat flow evolution of the Tabei Uplift in Tarim Basin, northwest China. Journal of Asian Earth Sciences, 37(1), 52-66.

Li, Z., Chen, H., Song, B., Li, Y., Yang, S., Yu, X. (2011), Temporal evolution of the Permian large igneous province in Tarim Basin in northwestern China. Journal of Asian Earth Sciences, 42(5), 917-927.

Licht, A., Dupont-Nivet, G., Win, Z., Swe, H. H., Kaythi, M., Roperch, P., ... \& Jones, D. (2018), Paleogene evolution of the Burmese forearc basin and implications for the history of India-Asia convergence. Geological Society of America Bulletin, 131(5-6), 730-748.

Licht, A., Win, Z., Westerweel, J., Cogné, N., Morley, C. K., Chantraprasert, S., ... \& Dupont-Nivet, G. (2020). Magmatic history of central Myanmar and implications for the evolution of the Burma Terrane. Gondwana Research, 87, 303-319.

Lin, C., Yang, H., Liu, J., Rui, Z., Cai, Z., Zhu, Y. (2012), Distribution and erosion of the Paleozoic tectonic unconformities in the Tarim Basin, Northwest China: significance for the evolution of paleo-uplifts and tectonic geography during deformation. Journal of Asian Earth Sciences, 46, 1-19.

Liu, E. T., Wang, H., Uysal, T., Zhao, J., Wang, X., Feng, Y. X., Pan, S. Q. (2017), Paleogene igneous intrusion and its effect on thermal maturity of organic-rich mudstones in the Beibuwan Basin, South China Sea. Marine and Petroleum Geology, 86, 733-750.

Liu, D. H., and Shi, J. Y. (1994), Study on the evaluation methods on high matured carbonate source rocks. Petroleum Exploration and Development, 21, 113-115.

Liu, H., Fang, N., Meng, J. (2015), Study on Calibration methods of erosion thickness and Paleotectonic reconstruction of Tarim Basin. Internal Report of SINOPEC Research Company.

Liu S., Lei, X., Feng, C., Hao, C. (2016), Estimation of subsurface formation temperature in the Tarim Basin, northwest China: implications for hydrocarbon generation and preservation. International Journal of Earth Sciences, 105(5), 1329-1351.

Liu, S., Li, X., Hao, C., Li, X. (2016), Heat flow, deep formation temperature and thermal structure of the Tarim basin, Northwest China. Earth Science Frontiers, 24(3), 41-55(in Chinese).

Liu, S., Wang, L., Li, C., Zhang, P., Li, H. (2006), Lithospheric thermo-rheological structure and Cenozoic thermal regime in the Tarim Basin, northwest China. ACTA GEOLOGICA SINICA-ENGLISH EDITION-, 80(3), 344.

Lloyd, M. K., Eiler, J. M., Nabelek, P. I. (2017), Clumped isotope thermometry of calcite and dolomite in a contact metamorphic environment. Geochimica et

This article is protected by copyright. All rights reserved. 
cosmochimica acta, 197, 323-344.

Lloyd, M. K., Ryb, U., Eiler, J. M. (2018), Experimental calibration of clumped isotope reordering in dolomite. Geochimica et Cosmochimica Acta, 242, 1-20.

Lü, X., Wang, Y., Yu, H., Bai, Z. (2017), Major factors affecting the closure of marine carbonate caprock and their quantitative evaluation: A case study of Ordovician rocks on the northern slope of the Tazhong uplift in the Tarim Basin, Western China. Marine and Petroleum Geology, 83, 231-245.

Lu, Z., Chen, H., Qing, H., Chi, G., Chen, Q., You, D., ... \& Zhang, S. (2017), Petrography, fluid inclusion and isotope studies in Ordovician carbonate reservoirs in the Shunnan area, Tarim basin, NW China: Implications for the nature and timing of silicification. Sedimentary Geology, 359, 29-43.

Lu Z.Y. (2018), Paleo-fluids and Hydrocarbon Accumulation Studies in the Ordovician Carbonate Reservoirs of the Shunnan and Guchengxu Areas, Tarim Basin. PhD thesis, China University of Geosciences, Wuhan.

Ludwig, K. R. (2012), User's Manual for Isoplot 3.75-4.15. A Geochronological Toolkit Microsoft Excel. Berkeley Geochronology Center, Special Publication, 5, $75 \mathrm{p}$.

MacDonald, J. M., Faithfull, J. W., Roberts, N. M. W., Davies, A. J., Holdsworth, C. M., Newton, M., Williamson, S., Boyce, A. \& John, C. M. (2019). Clumpedisotope palaeothermometry and LA-ICP-MS U-Pb dating of lava-pile hydrothermal calcite veins. Contributions to Mineralogy and Petrology, 174(7), 63.

Machel, H. G. (1985), Cathodoluminescence in calcite and dolomite and its chemical interpretation. Geoscience Canada, 12(4).

Mangenot, X., Deçoninck, J. F., Bonifacie, M., Rouchon, V., Collin, P. Y., Quesne, D., ... \& Sizun, J. P. (2018a), Thermal and exhumation histories of the northern subalpine chains (Bauges and Bornes-France): Evidence from forward thermal modeling coupling clay mineral diagenesis, organic maturity and carbonate clumped isotope $(\Delta 47)$ data. Basin Research, 31(2), 361-379.

Mangenot, X., Gasparrini, M., Gerdes, A., Bonifacie, M., and Rouchon, V. (2018b), An emerging thermochronometer for carbonate-bearing rocks: $\Delta 47 /(\mathrm{U}-\mathrm{Pb})$. Geology, 46 (12), 1067-1070.

Martin, L. G., Montañez, I. P., Bishop, J. W. (2012), A paleotropical carbonatedominated archive of Carboniferous icehouse dynamics, Bird Spring Fm., Southern Great Basin, USA. Palaeogeography, Palaeoclimatology, Palaeoecology, 329, 64-82.

Nabelek, P. I., Hofmeister, A. M., Whittington, A. G. (2012), The influence of temperature-dependent thermal diffusivity on the conductive cooling rates of plutons and temperature-time paths in contact aureoles. Earth and Planetary Science Letters, 317, 157-164.

This article is protected by copyright. All rights reserved. 
Methner, K., Mulch, A., Fiebig, J., Wacker, U., Gerdes, A., Graham, S.A., and Chamberlain, C.P. (2016), Rapid Middle Eocene temperature change in western North America. Earth and Planetary Science Letters, 450, 132-139.

Mueller, M., Igbokwe, O. A., Walter, B., Pederson, C. L., ... \& Immenhauser, A. (2020). Testing the preservation potential of early diagenetic dolomites as geochemical archives. Sedimentology, 67, 849-881.Nuriel, P., Weinberger, R., Kylander-Clark, A.R.C., Hacker, B.R., and Craddock, J.P. (2017), The onset of the Dead Sea transform based on calcite age-strain analyses. Geology, 45, 587590.

O’Neil, J. R., Clayton, R. N., Mayeda, T. K. (1969), Oxygen isotope fractionation in divalent metal carbonates. The Journal of Chemical Physics, 51(12), 5547-5558.

Pagel, M., Bonifacie, M., Schneider, D. A., Gautheron, C., Brigaud, B., Calmels, D., ... \& Davis, D. (2018), Improving paleohydrological and diagenetic reconstructions in calcite veins and breccia of a sedimentary basin by combining $\Delta 47$ temperature, $\delta^{18} \mathrm{O}_{\text {water }}$ and U-Pb age. Chemical Geology, 481, 1-17.

Parrish, R. R., Parrish, C. M., \& Lasalle, S. (2018), Vein calcite dating reveals Pyrenean orogen as cause of Paleogene deformation in southern England. Journal of the Geological Society, 175(3), 425-442.

Passey, B.H., Levin, N.E., Cerling, T.E., Brown, F.H., Eiler, J.M. (2010), Hightemperature environments of human evolution in East Africa based on bond ordering in paleosol carbonates. Proceedings of the National Academy of Sciences, 107, 11245-11249.

Passey, B. H., Henkes, G. A. (2012), Carbonate clumped isotope bond reordering and geospeedometry. Earth and Planetary Science Letters, 351, 223-236.

Paton, C., Woodhead, J., Hellstrom, J., Hergt, J., Greig, A. and Maas, R. (2010), Improved laser ablation U-Pb zircon geochronology through robust down-hole fractionation correction. Geochemistry, Geophysics, Geosystems, 11(3), doi:10.1029/2009GC002618.

Platte River Associates Inc. (2003), Basin 1-D manual to accompany the September 2000 release: 2790 Valmont Road, Boulder, Colorado 80304-2906, USA.

Qi, Y. A., Liu, G. C. (1999), Wave process analysis of sedimentary basin and erosion quantity of unconformities. Journal of Jiaozuo Institute of Technology, 18(3), 161-165(in Chinese with English abstract).

Qing, H., Veizer, J. (1994), Oxygen and carbon isotopic composition of Ordovician brachiopods: Implications for coeval seawater. Geochimica et Cosmochimica Acta, 58(20), 4429-4442.

Qiu, N. S. (2002), Thermal evaluation and hydrocarbon generation history of the sedimentary basins in western China. Petroleum Exploration and Development, 29(1), 6-8.

Qiu, N., Chang, J., Zuo, Y., Wang, J., Li, H. (2012), Thermal evolution and

This article is protected by copyright. All rights reserved. 
maturation of lower Paleozoic source rocks in the Tarim Basin, northwest China. AAPG bulletin, 96(5), 789-821.

Quade, J., Rasbury, E.T., Huntington, K.W., Hudson, A.M., Vonhof, H., Anchukaitis, K., Betancourt, J., Latorre, C., and Pepper, M. (2017), Isotopic characterization of late Neogene travertine deposits at Barrancas Blancas in the eastern Atacama Desert, Chile. Chemical Geology, 466, 41-56,

Rais, P., Louis-Schmid, B., Bernasconi, S. M., Weissert, H. (2007),

Palaeoceanographic and palaeoclimatic reorganization around the Middle-Late Jurassic transition. Palaeogeography, Palaeoclimatology, Palaeoecology, 251(34), 527-546.

Rasbury E. T., Cole, J. (2009), Directly dating geologic events: U-Pb dating of carbonates. Review of Geophysics, 47, 1-27.

Roberts, N.M.W., and Walker, R.J. (2016), U-Pb geochronology of calcitemineralized faults: Absolute timing of rift-related fault events on the northeast Atlantic margin: Geology, 44, 531-534.

Roberts, N. M., Rasbury, E. T., Parrish, R. R., Smith, C. J., Horstwood, M. S., \& Condon, D. J. (2017), A calcite reference material for LA $\square \mathrm{ICP} \square \mathrm{MS} \mathrm{U} \square \mathrm{Pb}$ geochronology. Geochemistry, Geophysics, Geosystems, 18(7), 2807-2814.

Ryb, U., Eiler, J. M. (2018), Oxygen isotope composition of the Phanerozoic ocean and a possible solution to the dolomite problem. Proceedings of the National Academy of Sciences, 115(26), 6602-6607.

Ryb U., Lloyd M. K., Stolper D. A. and Eiler J. M. (2017), The clumped-isotope geochemistry of exhumed marbles from Naxos, Greece. Earth and Planetary Science Letters. 470, 1-12.

Schauble, E.A., Ghosh, P., Eiler, J.M. (2006), Preferential formation of 13C-18O bonds in carbonate minerals, estimated using first-principles lattice dynamics. Geochimica et Cosmochimica Acta, 70 (10), 2510-2529.

Shen, W., Chen, J., Wang, Y., Zhang, K., Chen, Z., Luo, G., Fu, X. (2019), The origin, migration and accumulation of the Ordovician gas in the Tazhong III region, Tarim Basin, NW China. Marine and Petroleum Geology, 101, 55-77.

Shenton, B. J., Grossman, E. L., Passey, B. H., Henkes, G. A., Becker, T. P., Laya, J. C., ... Lawson, M. (2015), Clumped isotope thermometry in deeply buried sedimentary carbonates: The effects of bond reordering and recrystallization. GSA Bulletin, 127(7-8), 1036-1051.

Stewart, A. K., Massey, M., Padgett, P. L., Rimmer, S. M., Hower, J. C. (2005), Influence of a basic intrusion on the vitrinite reflectance and chemistry of the Springfield (No. 5) coal, Harrisburg, Illinois. International Journal of Coal Geology, 63(1-2), 58-67.

Stolper, D. A., Eiler, J. M. (2015), The kinetics of solid-state isotope-exchange reactions for clumped isotopes: A study of inorganic calcites and apatites from

This article is protected by copyright. All rights reserved. 
natural and experimental samples. American Journal of Science, 315(5), 363411.

Sweeney, J. J., Burnham, A. K. (1990), Evaluation of a simple model of vitrinite reflectance based on chemical kinetics (1). AAPG bulletin, 74(10), 1559-1570.

Veizer J., Bruckschen, P., Oesmann, S. (1999), Isotope stratigraphy of the European Carboniferous: proxy signals for ocean chemistry, climate and tectonics. Chemical Geology, 161(1-3): 127-163.

Veizer, J., Prokoph, A. (2015), Temperatures and oxygen isotopic composition of Phanerozoic oceans. Earth-Science Reviews, 146, 92-104.

Wadleigh M.A., Veizer J. (1992), ${ }^{18} \mathrm{O} /{ }^{16} \mathrm{O}$ and ${ }^{13} \mathrm{C} /{ }^{12} \mathrm{C}$ in Lower Paleozoic brachiopods: isotopic composition of sea water. Geochimica et Cosmochimica Acta, 56, 431-443.

Wang, T. G., Song, D. F., Li, M. J., Yang, C. Y., Ni, Z. Y., Li, H. L., ... \& Feng, Z. H. (2014), Natural gas source and deep gas exploration potential of the Ordovician Yingshan Formation in the Shunnan-Gucheng region, Tarim Basin. Oil and Gas Geology, 35(6), 753-762.

Wang, T., Dai, S., Li, M., Zhang, W., Qiu, N., Wang, G. (2010), Stratigraphic thermohistory and its implications for regional geoevolution in the Tarim Basin, NW China. Science China Earth Sciences, 53(10), 1495-1505.

Wei, X., Xu, Y. G., Feng, Y. X., Zhao, J. X. (2014), Plume-lithosphere interaction in the generation of the Tarim large igneous province, NW China:

Geochronological and geochemical constraints. American Journal of Science, 314(1), 314-356.

Wilkins, R.W.T., Boudou, R., Sherwood, N., Xiao, X.M. (2014), Thermal maturity evaluation from inertinites by Raman spectroscopy: The 'RaMM' technique. International Journal of Coal Geology, 128-129, 143-152.

Woodhead, J.D., and Hergt, J.M. (2001), Strontium, neodymium and lead isotope analyses of NIST glass certified reference materials: SRM 610, 612, 614. Geostandards Newsletter, 25, 261-266.

Wu, B. (2015), Transformation of Critical Tectonic Regimes and Its Mechanisms in Eastern Tarim Basin: Implications for Tectonic Controls on Oil and Gas Occurrence. PhD thesis, China University of Geosciences, Beijing.

Xu, Q., Qiu, N., Liu, W., Chang, Q. (2018), Reconstructing the basin thermal history with clumped isotope. Chinese Science Bulletin.

Xu, Y. G., Wei, X., Luo, Z. Y., Liu, H. Q., Cao, J. (2014), The Early Permian Tarim Large Igneous Province: main characteristics and a plume incubation model. Lithos, 204, 20-35.

Yang, S., Chen, H., Li, Z., Li, Y., Yu, X., Li, D., Meng, L. (2013), Early Permian Tarim large igneous province in northwest China. Science China Earth Sciences,

This article is protected by copyright. All rights reserved. 
56(12), 2015-2026.

Yao, Z., He, G., Li, C.F. and Dong, C. (2018), Sill geometry and emplacement controlled by a major disconformity in the Tarim Basin, China: Earth and Planetary Science Letters, 501, 37-45.

Yu, X., Yang, S. F., Chen, H. L., Chen, Z. Q., Li, Z. L., Batt, G. E., Li, Y. Q. (2011), Permian flood basalts from the Tarim Basin, Northwest China: SHRIMP zircon U-Pb dating and geochemical characteristics. Gondwana Research, 20(2-3), 485497.

Zhang, C. L., Zou, H. B., Li, H. K., Wang, H. Y. (2013), Tectonic framework and evolution of the Tarim Block in NW China. Gondwana Research, 23(4), 13061315.

Zhang, D., Zhang, Z., Mao, J., Huang, H., Cheng, Z. (2016), Zircon U-Pb ages and Hf-O isotopic signatures of the Wajilitag and Puchang Fe-Ti oxide-bearing intrusive complexes: constraints on their source characteristics and temporalspatial evolution of the Tarim large igneous province. Gondwana Research, 37, 71-85.

Zhang, S., Huang, H., Su, J., Liu, M., Wang, X. and Hu, J. (2015), Geochemistry of Paleozoic marine petroleum from the Tarim Basin, NW China: Part 5. Effect of maturation, TSR and mixing on the occurrence and distribution of alkyldibenzothiophenes: Organic geochemistry, 86, 5-18.

Zhang, Y. W., Jin, Z. J., Liu, G. C., Li, J. C. (2000), Study on the formation of unconformities and the amount of eroded sedimentation in Tarim basin. Earth Science Frontiers, 7(4), 449-457 (in Chinese with English abstract).

Zhang, Y., Munnecke, A. (2016), Ordovician stable carbon isotope stratigraphy in the Tarim Basin, NW China. Palaeogeography, Palaeoclimatology, Palaeoecology, 458, 154-175.

Zhu, C., Hu, S., Qiu, N., Jiang, Q., Rao, S., Liu, S. (2018), Geothermal constraints on Emeishan mantle plume magmatism: paleotemperature reconstruction of the Sichuan Basin, SW China. International Journal of Earth Sciences, 107(1), 7188.

Zhu, C., Hu, S., Qiu, N., Rao, S., Yuan, Y. (2016), The thermal history of the Sichuan Basin, SW China: Evidence from the deep boreholes. Science China Earth Sciences, 59(1), 70-82.

Zhu, G., Zhang, S., Su, J., Meng, S., Yang, H., Hu, J. and Zhu, Y. (2013), Secondary accumulation of hydrocarbons in Carboniferous reservoirs in the northern Tarim Basin, China. Journal of Petroleum Science and Engineering, 102, 10-26.

This article is protected by copyright. All rights reserved. 
Table 1. Average isotope and clumped isotope data for each sample

\begin{tabular}{|c|c|c|c|c|c|c|c|c|c|c|c|c|c|c|c|}
\hline Sample & Fabrics $^{a}$ & $\begin{array}{l}\text { Depth }^{\mathrm{b}} \\
\text { (m) }\end{array}$ & $\mathrm{N}^{\mathrm{c}}$ & $\begin{array}{c}\delta^{13} \mathbf{C} \\
(\%, \text { VPDB })\end{array}$ & $\begin{array}{r} \pm 1 \\
\text { S.D. }\end{array}$ & $\begin{array}{c}\delta^{18} \mathbf{O} \\
(\%, \text { VPDB })\end{array}$ & $\begin{array}{r} \pm 1 \\
\text { S.D. }\end{array}$ & $\begin{array}{c}\Delta_{47}{ }^{d} \\
(\% c, \mathrm{ARF})\end{array}$ & $\begin{array}{c} \pm 1 \\
\text { S.E. }\end{array}$ & $\begin{array}{c}\left.\mathrm{T} \Delta_{47}(\square)\right)^{\mathrm{e}} \\
\text { (Bonifacie et al., 2017) }\end{array}$ & $\begin{array}{r} \pm 1 \\
\text { S.E. }\end{array}$ & $\begin{array}{c}\mathrm{T} \Delta_{47}(\square)^{\mathrm{f}} \\
\text { (Schauble et al., 2006) }\end{array}$ & $\begin{array}{r} \pm 1 \\
\text { S.E. }\end{array}$ & $\begin{array}{c}\delta^{18} \mathbf{O}_{\text {water }}{ }^{\mathrm{g}} \\
(\% c, \text { VSMOW) }\end{array}$ & $\begin{array}{r} \pm 1 \\
\text { S.E. }\end{array}$ \\
\hline \multicolumn{16}{|l|}{ Tabei Area } \\
\hline TS301-CT1 & Micrite & 6131.10 & 3 & -0.66 & 0.26 & -6.90 & 0.15 & 0.565 & 0.002 & 76 & 1 & 72 & 1 & 4.03 & 0.10 \\
\hline TS301-CT2 & Micrite & 6127.10 & 4 & -0.53 & 0.25 & -6.94 & 0.22 & 0.560 & 0.004 & 78 & 2 & 74 & 2 & 4.31 & 0.31 \\
\hline ТP18-СТ3 & Micrite & 6827.02 & 3 & -0.34 & 0.28 & -6.48 & 0.71 & 0.553 & 0.011 & 82 & 6 & 78 & 6 & 5.29 & 1.13 \\
\hline TP18-CT4 & Micrite & 6751.60 & 3 & -0.26 & 0.01 & -6.69 & 0.23 & 0.562 & 0.004 & 77 & 2 & 73 & 2 & 4.46 & 0.37 \\
\hline ТP18-СТ5 & Vein & 6751.60 & 2 & 0.55 & 0.00 & -6.57 & 0.15 & 0.557 & 0.013 & 80 & 7 & 76 & 7 & 4.92 & 0.97 \\
\hline \multicolumn{16}{|l|}{ Shunbei Area } \\
\hline SHB2-CT6 & Micrite & 7523.93 & 3 & -0.79 & 0.02 & -5.87 & 0.10 & 0.523 & 0.003 & 99 & 2 & 94 & 2 & 7.83 & 0.29 \\
\hline SHB2-CT7 & Micrite & 7443.00 & 3 & -2.83 & 0.19 & -6.07 & 0.09 & 0.527 & 0.004 & 96 & 2 & 92 & 2 & 7.37 & 0.25 \\
\hline SHB2-CT8 & Micrite & 7441.70 & 4 & -0.36 & 0.54 & -6.27 & 0.37 & 0.532 & 0.004 & 94 & 2 & 89 & 2 & 6.85 & 0.32 \\
\hline SHB2-CT9 & Micrite & 7735.80 & 3 & -3.08 & 0.05 & -5.94 & 0.01 & 0.524 & 0.002 & 99 & 1 & 94 & 1 & 7.74 & 0.14 \\
\hline SHB2-CT10 & Cement & 7441.70 & 1 & 0.00 & 0.01 & -7.25 & 0.03 & 0.524 & 0.007 & 98 & 4 & 93 & 4 & 6.39 & 0.42 \\
\hline SHB2-CT11 & Vein & 7735.80 & 3 & -2.37 & 0.11 & -7.77 & 0.26 & 0.479 & 0.009 & 125 & 7 & 123 & 7 & 8.52 & 0.48 \\
\hline \multicolumn{16}{|l|}{ Shuntuo Area } \\
\hline ST1-CT12 & Micrite & 7861.33 & 3 & -1.15 & 0.09 & -5.50 & 0.06 & 0.449 & 0.007 & 154 & 6 & 147 & 6 & 13.15 & 0.42 \\
\hline ST1-CT13 & Micrite & 7862.50 & 3 & -0.99 & 0.34 & -5.69 & 0.23 & 0.445 & 0.010 & 159 & 10 & 151 & 10 & 13.27 & 0.78 \\
\hline ST1-CT14 & Cement & 7861.14 & 1 & -0.85 & 0.00 & -3.57 & 0.01 & 0.444 & 0.015 & 159 & 14 & 151 & 13 & 15.44 & 0.99 \\
\hline \multicolumn{16}{|l|}{ Shunnan Area } \\
\hline SN4-CT15 & Micrite & 6570.00 & 3 & 0.21 & 0.02 & -6.98 & 0.01 & 0.431 & 0.004 & 172 & 4 & 163 & 4 & 12.82 & 0.27 \\
\hline SN4-CT16 & Micrite & 6466.10 & 3 & 0.09 & 0.00 & -6.81 & 0.03 & 0.420 & 0.002 & 184 & 3 & 175 & 2 & 13.72 & 0.15 \\
\hline SN5-2-CT17 & Micrite & 6870.82 & 3 & -1.14 & 0.12 & -7.60 & 0.10 & 0.418 & 0.005 & 186 & 5 & 177 & 5 & 13.08 & 0.25 \\
\hline \multicolumn{16}{|l|}{ Gulong Area } \\
\hline GL3-CT18 & Micrite & 6068.50 & 3 & -0.54 & 0.05 & -7.22 & 0.13 & 0.440 & 0.004 & 163 & 4 & 155 & 4 & 11.98 & 0.29 \\
\hline GL3-CT19 & Micrite & 6062.82 & 3 & -0.68 & 0.05 & -7.18 & 0.10 & 0.444 & 0.009 & 159 & 9 & 152 & 9 & 11.79 & 1.03 \\
\hline GL3-CT20 & Vein & 6062.82 & 1 & -0.98 & 0.02 & -9.93 & 0.01 & 0.429 & 0.017 & 174 & 18 & 166 & 17 & 9.88 & 1.13 \\
\hline
\end{tabular}

Note: Errors of $\delta^{13} \mathrm{C}$ and $\delta^{18} \mathrm{O}$ are reported as $1 \mathrm{SD}$ of replicate analyses, and errors of $\Delta_{47}, \mathrm{~T} \Delta_{47}$ and $\delta^{18} \mathrm{O}_{\text {water }}$ are reported as $1 \mathrm{SE}$ of replicate analyses. For singly measured samples, the errors are reported using internal

measurement standard deviations or standard errors. VPDB—Vienna Peedee Belemnite.

${ }^{\mathrm{a}}$ Calcite fabric used for measurements.

${ }^{\mathrm{b}}$ Subsurface burial depths of samples.

${ }^{\mathrm{c}}$ Number of replicates for analysis. 
${ }^{d}$ Carbonate clumped isotope values after acid correction are reported in the absolute reference frame (Dennis et al., 2011)

${ }^{\mathrm{e}} \mathrm{T} \Delta_{47}$ was calibrated using the universal $\Delta_{47}$-temperature equation of Bonifacie et al., (2017).

${ }^{\mathrm{f}} \mathrm{T} \Delta_{47}$ was calibrated using the theoretical $\Delta_{47}$-temperature equation of Schauble et al., (2006).

${ }^{\mathrm{g}}$ Apparent water oxygen isotope compositions of the precipitating waters $\left(\delta^{18} \mathrm{O}_{\text {water }}\right)$ were calculated using the calcite-water oxygen isotope thermometry equation from O'Neil et al. (1969). VSMOW-Vienna standard mean ocean water.

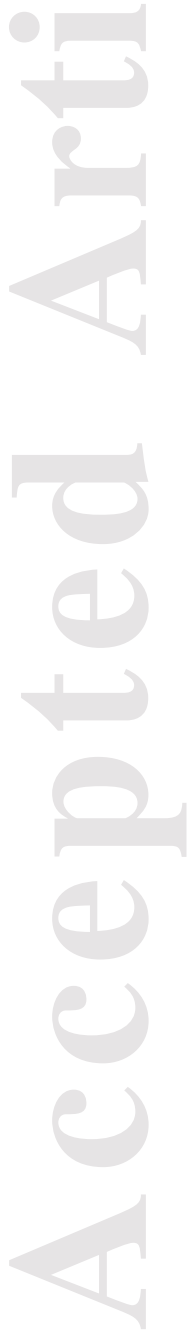


Table 2. Average isotope and clumped isotope data for each well

\begin{tabular}{|c|c|c|c|c|c|c|c|c|c|c|c|c|c|c|c|}
\hline Wells & Burial T ( $\square)^{\text {a }}$ & Fabrics $^{\text {b }}$ & $\mathbf{N}^{\mathrm{c}}$ & $\begin{array}{c}\delta^{13} \mathbf{C} \\
(\%, \text { VPDB })\end{array}$ & $\begin{array}{r} \pm 1 \\
\text { S.D. }\end{array}$ & $\begin{array}{c}\delta^{18} \mathbf{O} \\
(\%, \text { VPDB })\end{array}$ & $\begin{array}{r} \pm 1 \\
\text { S.D. }\end{array}$ & $\begin{array}{c}\Delta_{47}{ }^{\mathrm{d}} \\
(\%, \text { ARF })\end{array}$ & $\begin{array}{r} \pm 1 \\
\text { S.E. }\end{array}$ & $\begin{array}{c}\mathrm{T} \Delta_{47}(\square)^{\mathrm{e}} \\
\text { (Bonifacie et al., 2017) }\end{array}$ & $\begin{array}{r} \pm 1 \\
\text { S.E. }\end{array}$ & $\begin{array}{c}T \Delta_{47}(\square)^{f} \\
\text { (Schauble et al., 2006) }\end{array}$ & $\begin{array}{r} \pm 1 \\
\text { S.E. }\end{array}$ & $\begin{array}{c}\delta^{18} \mathbf{O}_{\text {water }}{ }^{\mathrm{g}} \\
(\%, \text { VSMOW) }\end{array}$ & $\begin{array}{r} \pm 1 \\
\text { S.E. }\end{array}$ \\
\hline TS301 & 131 & Micrite & 7 & -0.59 & 0.25 & -6.92 & 0.18 & 0.562 & 0.006 & 77 & 1 & 73 & 1 & 4.19 & 0.18 \\
\hline \multirow{2}{*}{ TP18 } & \multirow{2}{*}{145} & Micrite & 6 & -0.30 & 0.19 & -6.59 & 0.48 & 0.557 & 0.006 & 80 & 3 & 76 & 3 & 4.86 & 0.56 \\
\hline & & Vein & 2 & 0.55 & 0.00 & -6.57 & 0.15 & 0.557 & 0.013 & 80 & 7 & 76 & 7 & 4.92 & 0.97 \\
\hline \multirow{3}{*}{ SHB2 } & \multirow{3}{*}{163} & Micrite & 13 & -1.66 & 1.30 & -6.05 & 0.26 & 0.527 & 0.002 & 97 & 1 & 92 & 1 & 7.40 & 0.17 \\
\hline & & Cement & 1 & 0.00 & 0.01 & -7.25 & 0.03 & 0.524 & 0.007 & 98 & 4 & 93 & 4 & 6.39 & 0.42 \\
\hline & & Vein & 3 & -2.37 & 0.11 & -7.77 & 0.26 & 0.479 & 0.009 & 125 & 7 & 123 & 7 & 8.52 & 0.48 \\
\hline \multirow{2}{*}{ ST1 } & \multirow{2}{*}{188} & Micrite & 6 & -1.07 & 0.24 & -5.59 & 0.18 & 0.447 & 0.005 & 157 & 5 & 149 & 5 & 13.17 & 0.40 \\
\hline & & Cement & 1 & -0.85 & 0.00 & -3.57 & 0.01 & 0.444 & 0.015 & 159 & 14 & 151 & 13 & 15.44 & 0.99 \\
\hline SN4 & 178 & Micrite & 6 & 0.15 & 0.06 & -6.90 & 0.09 & 0.426 & 0.003 & 178 & 3 & 169 & 3 & 13.27 & 0.24 \\
\hline SN5-2 & 191 & Micrite & 3 & -1.14 & 0.12 & -7.60 & 0.10 & 0.418 & 0.005 & 186 & 5 & 177 & 5 & 13.07 & 5.29 \\
\hline \multirow{2}{*}{ GL3 } & \multirow{2}{*}{160} & Micrite & 6 & -0.61 & 0.09 & -7.20 & 0.10 & 0.442 & 0.005 & 161 & 5 & 153 & 4 & 14.97 & 1.68 \\
\hline & & Vein & 1 & -0.98 & 0.02 & -9.93 & 0.01 & 0.429 & 0.017 & 174 & 18 & 166 & 17 & 9.88 & 1.13 \\
\hline
\end{tabular}

Note: Errors of $\delta^{13} \mathrm{C}$ and $\delta^{18} \mathrm{O}$ are reported as $1 \mathrm{SD}$ of replicate analyses, and errors of $\Delta_{47}, \mathrm{~T} \Delta_{47}$ and $\delta^{18} \mathrm{O}_{\text {water }}$ are reported as $1 \mathrm{SE}$ of replicate analyses. For singly measured samples, the errors are reported using internal measurement standard deviations or standard errors. VPDB—Vienna Peedee Belemnite.

${ }^{\text {a }}$ Average burial temperatures of samples.

${ }^{\mathrm{b}}$ Calcite fabrics used for measurements.

${ }^{\mathrm{c}}$ Number of replicates for analysis

${ }^{\mathrm{d}}$ Carbonate clumped isotope values after acid correction are reported in the absolute reference frame (Dennis et al., 2011)

${ }^{\mathrm{e}} \mathrm{T} \Delta_{47}$ was calibrated using the universal $\Delta_{47}$-temperature equation of Bonifacie et al., (2017).

${ }^{\mathrm{f}} \mathrm{T} \Delta_{47}$ was calibrated using the theoretical $\Delta_{47}$-temperature equation of Schauble et al., (2006)

g Apparent water oxygen isotope compositions of the precipitating waters $\left(\delta^{18} \mathrm{O}_{\text {water }}\right)$ were calculated using the calcite-water oxygen isotope thermometry equation from O'Neil et al. (1969). VSMOW-Vienna standard mean ocean water. 
Table 3. Geothermally simulated erosion thickness and calculated geothermal gradients $(\square / \mathrm{km})$ at the time of thermal pulse.

\begin{tabular}{lc|c} 
& Erosion Hypothesis & Mantle Plume Hypothesis \\
\cline { 2 - 3 } Wells & Simulated Erosion $(\mathbf{k m})$ & Geothermal Gradients $(\square / \mathbf{k m})$ \\
TS301 & 6490 & 69.3 \\
TP18 & 5720 & 52.2 \\
SHB2 & 5860 & 46.3 \\
ST1 & 3240 & 31.8 \\
SN4 & - & 27.3 \\
SN5-2 & - & 26.8 \\
GL3 & - & 26.6 \\
\hline
\end{tabular}

Note: Erosion was simulated assuming Permian late-Permian erosion event was the sole cause for peak burial temperatures. SN4, SN5-2 and GL3 wells were not included in erosion simulation, since they did not show thermal pulse at that time. Geothermal gradients were calculated in $280 \mathrm{Ma}$ at the time of modeled peak burial temperatures to account for the hypothesis that mantle plume caused a thermal pulse during Permian.

This article is protected by copyright. All rights reserved. 


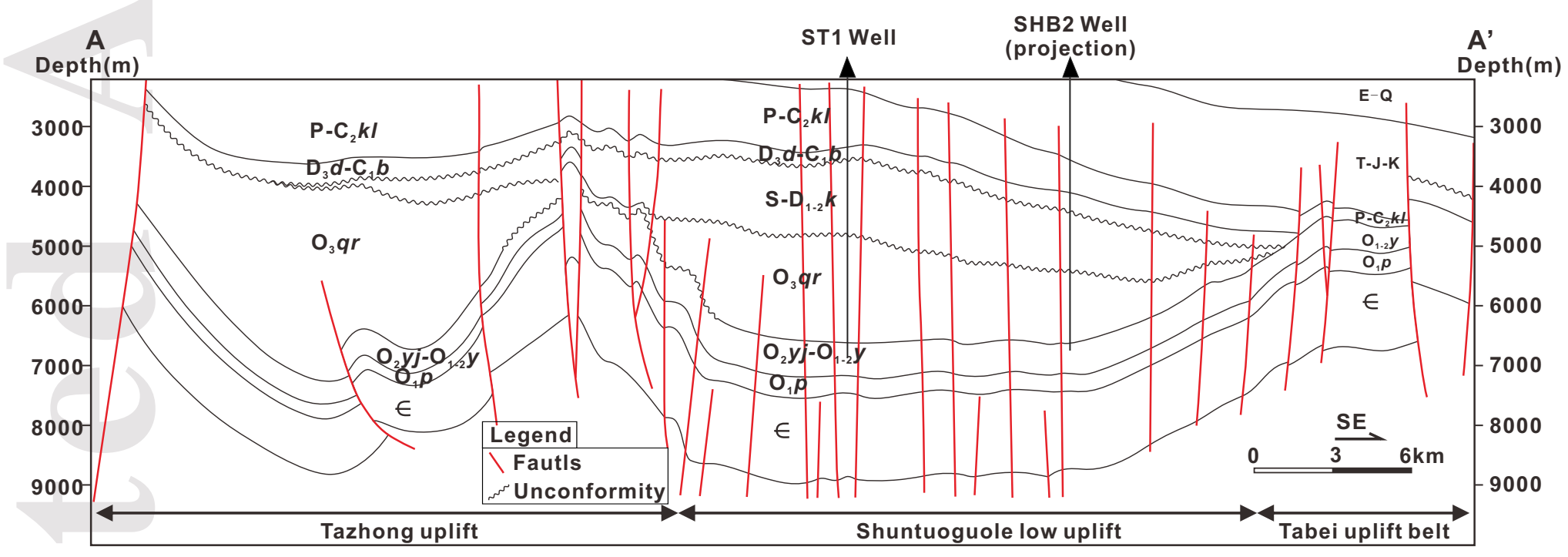

This article is protected by copyright. All rights reserved. 


\begin{tabular}{|c|c|c|c|c|c|c|}
\hline \multicolumn{2}{|c|}{ System } & $\begin{array}{l}\text { Age } \\
\text { (Ma) }\end{array}$ & Formation & \multicolumn{2}{|r|}{ Lithology } & Tectonic \\
\hline \multirow{4}{*}{ 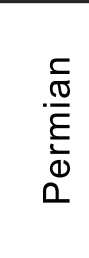 } & $\mathrm{P}_{3}$ & \multirow{4}{*}{-270.6} & Shajinzi & $\begin{array}{l}\cdot \cdot \cdot \\
\cdot \cdot\end{array}$ & Sandstone & \multirow{4}{*}{$\begin{array}{l}\text { Late } \\
\text { Hercynian } \\
\text { movement }\end{array}$} \\
\hline & \multirow{2}{*}{$\mathrm{P}_{2}$} & & Kaipaileizike & $\Gamma$ & \multirow{2}{*}{$\begin{array}{l}\text { Sandstone, siltstone, } \\
\text { basalt, tuff }\end{array}$} & \\
\hline & & & Kupukuziman & $\hat{r}$ & & \\
\hline & $P_{1}$ & & Nanzha & & Mudstone, limestone & \\
\hline \multirow{3}{*}{ 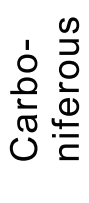 } & \multirow{2}{*}{$\mathrm{C}_{2}$} & \multirow{3}{*}{-318.1} & Xiaohaizi & & \multirow{2}{*}{ Mudstone, limestone } & \multirow{3}{*}{$\begin{array}{l}\text { Middle } \\
\text { Hercynian } \\
\text { movement }\end{array}$} \\
\hline & & & Kalashayi & \begin{tabular}{|l}
--- \\
--
\end{tabular} & & \\
\hline & $\mathrm{C}_{1}$ & & Bachu & \begin{tabular}{|l}
$-\quad-$ \\
\end{tabular} & Sandstone, mudstone & \\
\hline \multirow{2}{*}{ 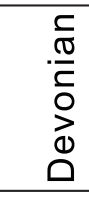 } & D3 & 359.2 & \multirow{3}{*}{ Keziertage } & $\cdot$ & Sandstone, mudstone & \multirow{2}{*}{$\begin{array}{l}\text { Late } \\
\text { Hercynian } \\
\text { movement }\end{array}$} \\
\hline & $\mathrm{D}_{1-2}$ & $\begin{array}{l}-385.3- \\
-416-\end{array}$ & & & \multirow{2}{*}{$\begin{array}{l}\text { Sandstone, siltstone, } \\
\text { mudstone }\end{array}$} & \\
\hline \multirow{4}{*}{$\frac{\frac{c}{3}}{\frac{3}{3}}$} & $\mathrm{~S}_{3}$ & \multirow{4}{*}{$\begin{array}{l}-422.9 \\
-428.2\end{array}$} & & $\cdot$ & & \multirow{3}{*}{$\begin{array}{c}\text { Early } \\
\text { Caledonian } \\
\text { movement }\end{array}$} \\
\hline & $\mathrm{S}_{2}$ & & Yimugantawu & $-\dot{0}$ & \multirow{3}{*}{ Siltstone, mudstone } & \\
\hline & \multirow{2}{*}{$\mathrm{S}_{1}$} & & Tataaiertage & & & \\
\hline & & & Kepinatage & & & \\
\hline \multirow{6}{*}{$\begin{array}{l}\frac{c}{0} \\
\frac{.0}{0} \\
\frac{0}{0} \\
\frac{0}{0}\end{array}$} & \multirow{3}{*}{$\mathrm{O}_{3}$} & & Queerqueke & \begin{tabular}{|l|}
- \\
- \\
- \\
-
\end{tabular} & \multirow{2}{*}{ Siltstone, mudstone } & \multirow{6}{*}{$\begin{array}{l}\text { Middle } \\
\text { Caledonian } \\
\text { movement }\end{array}$} \\
\hline & & & & & & \\
\hline & & (2) & Qiaerbake & & Marlstone, limestone & \\
\hline & ح & 400.0 & Yijianfang & & $\longrightarrow$ Disconformity & \\
\hline & & $17+2$ & Yingshan & & Limestone, & \\
\hline & $\mathrm{O}_{1}$ & $4 T 1.0$ & Penglaiba & & dolomitic limestone, & \\
\hline & $\in_{3}$ & & Qiulitage & & & \\
\hline$\frac{\pi}{2}$ & $\sigma \rho$ & & Awatage & & & \\
\hline$\frac{E}{\sigma}$ & (2) & & Shayilike & $\perp$ & Dolomite limestone & Early \\
\hline 0 & & $-510-$ & Wusonggeer & $1,1,1$ & & $\begin{array}{l}\text { Caledonian } \\
\text { movement }\end{array}$ \\
\hline & $\in_{1}$ & & Xiaoerbulake & 1,1 & & \\
\hline & & & Yuertusi & $\frac{---}{---}$ & Mudstone & \\
\hline & & & Precambrian se & ments and & basement $(A n \in)$ & \\
\hline $\begin{array}{l}\ddots \ddots \\
\ddots\end{array}$ & $\ddot{\varphi}$ & \% & 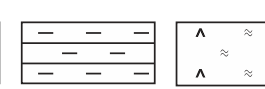 & $\frac{1,1}{1,1}$ & 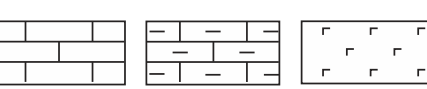 & \begin{tabular}{|l|l|}
1 & \\
1 & \\
\end{tabular} \\
\hline Sand & one & Siltstone & Mudstone Tuff & Dolomite & imestone Marlstone Basalt & $\begin{array}{l}\text { Dolomitic } \\
\text { limestone }\end{array}$ \\
\hline
\end{tabular}

This article is protected by copyright. All rights reserved. 


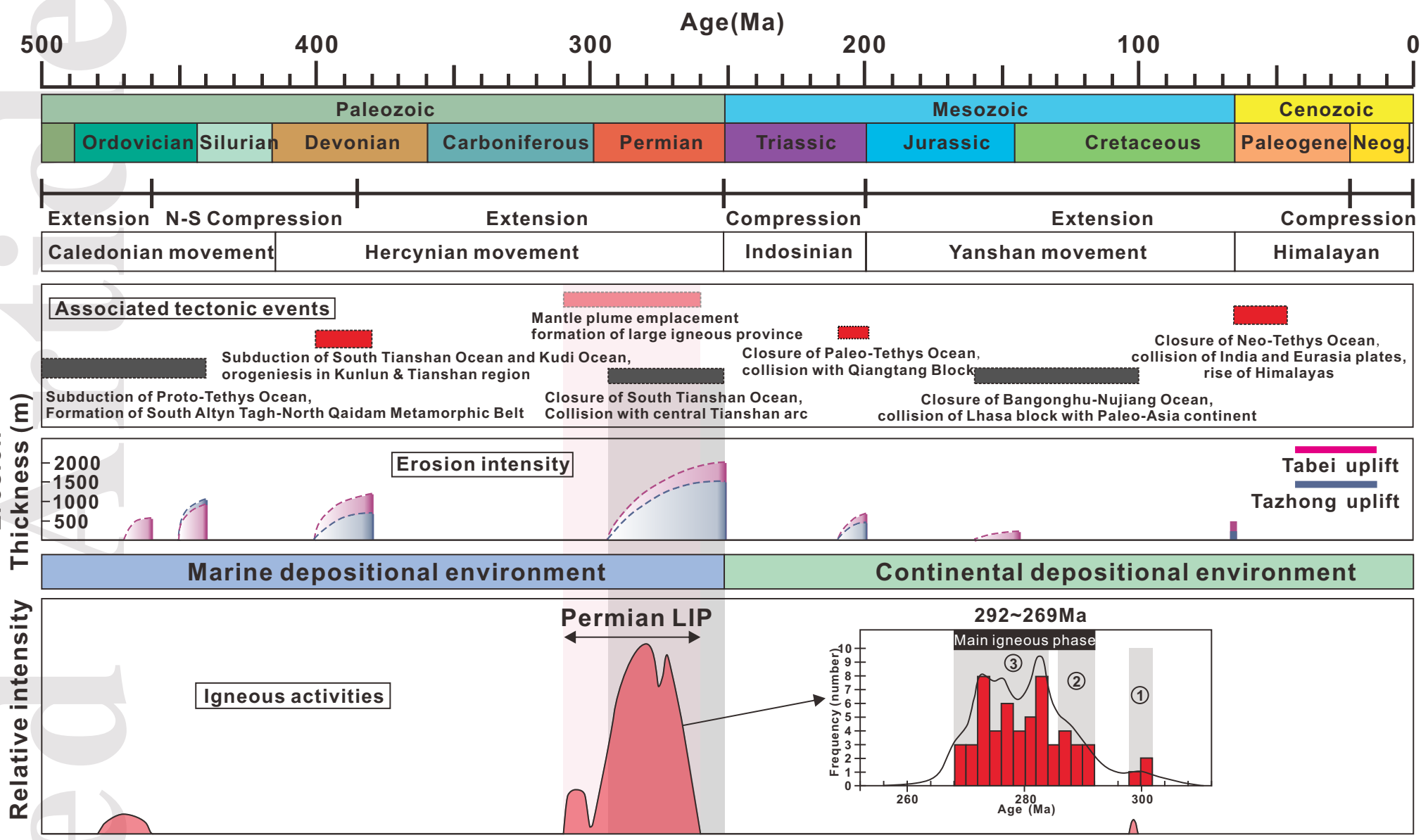

This article is protected by copyright. All rights reserved. 


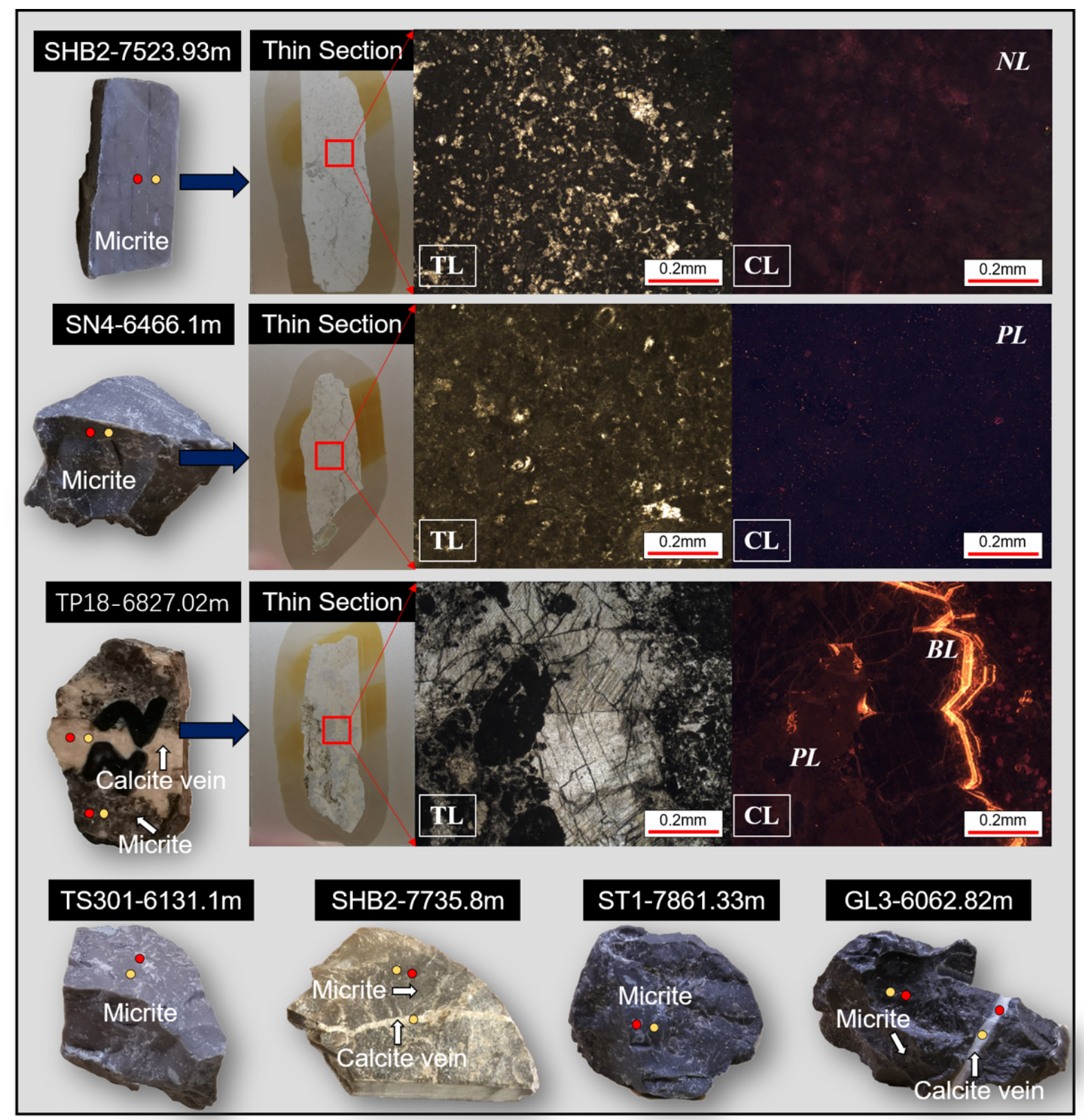

This article is protected by copyright. All rights reserved. 


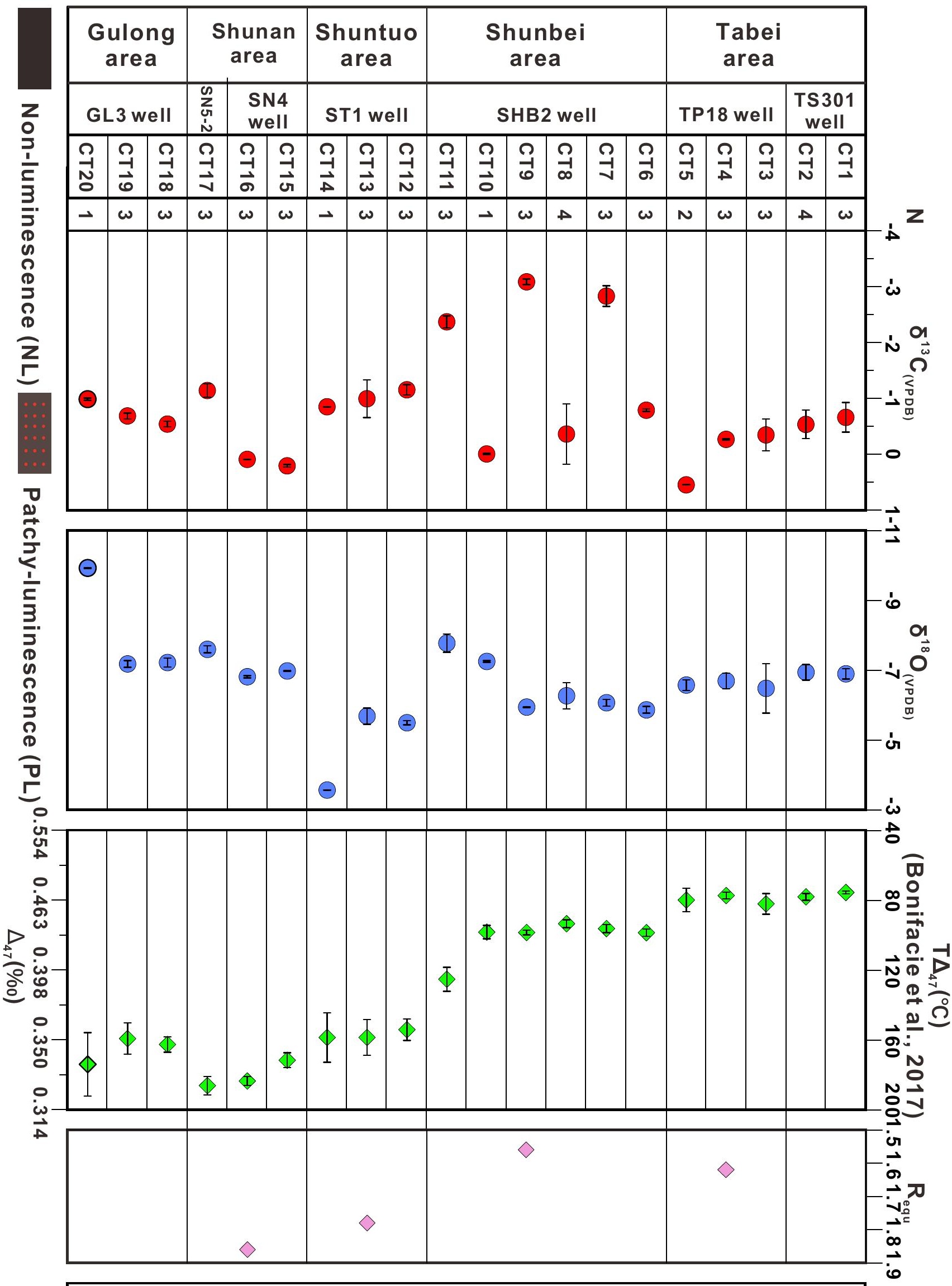



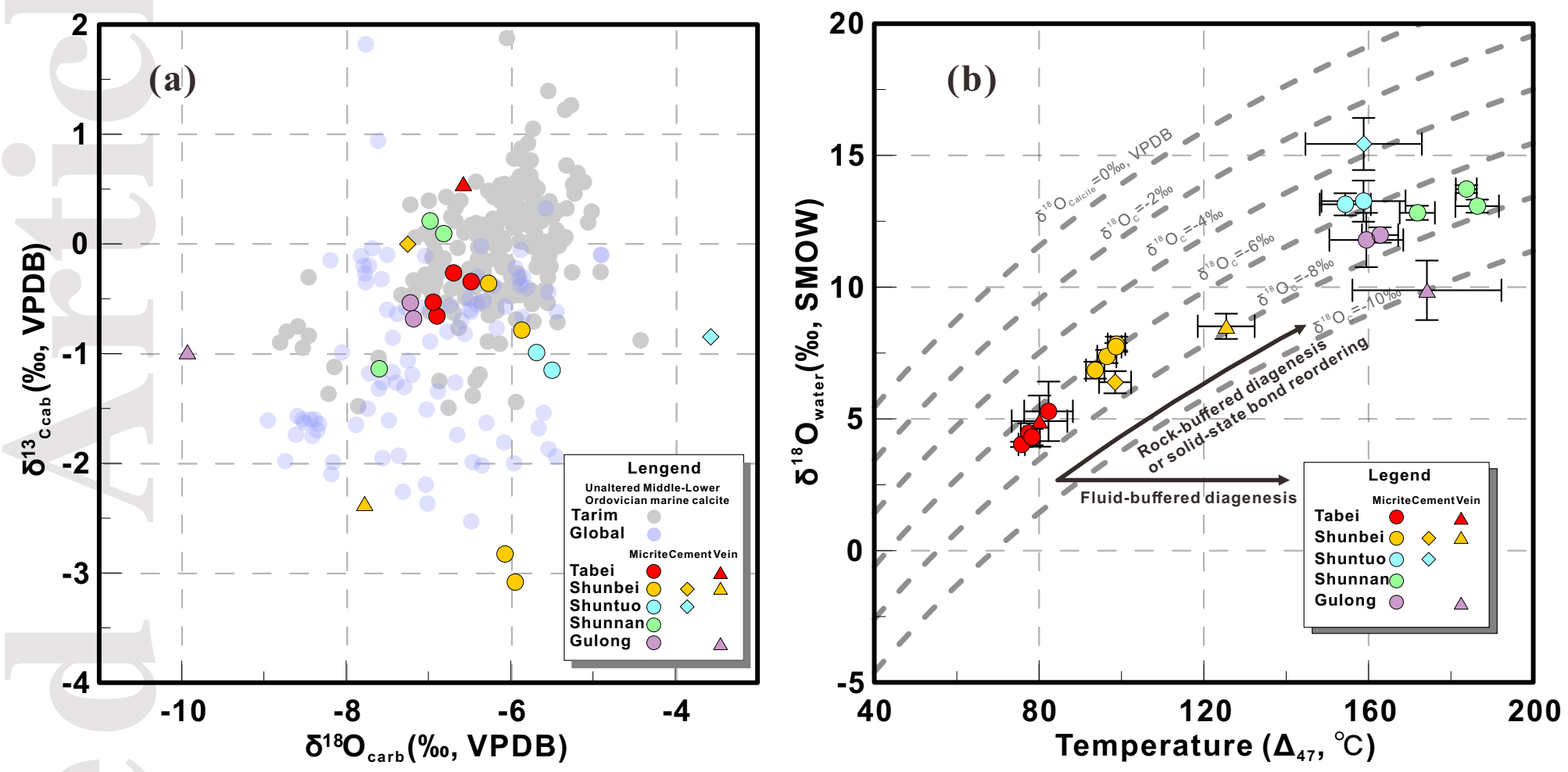

This article is protected by copyright. All rights reserved. 

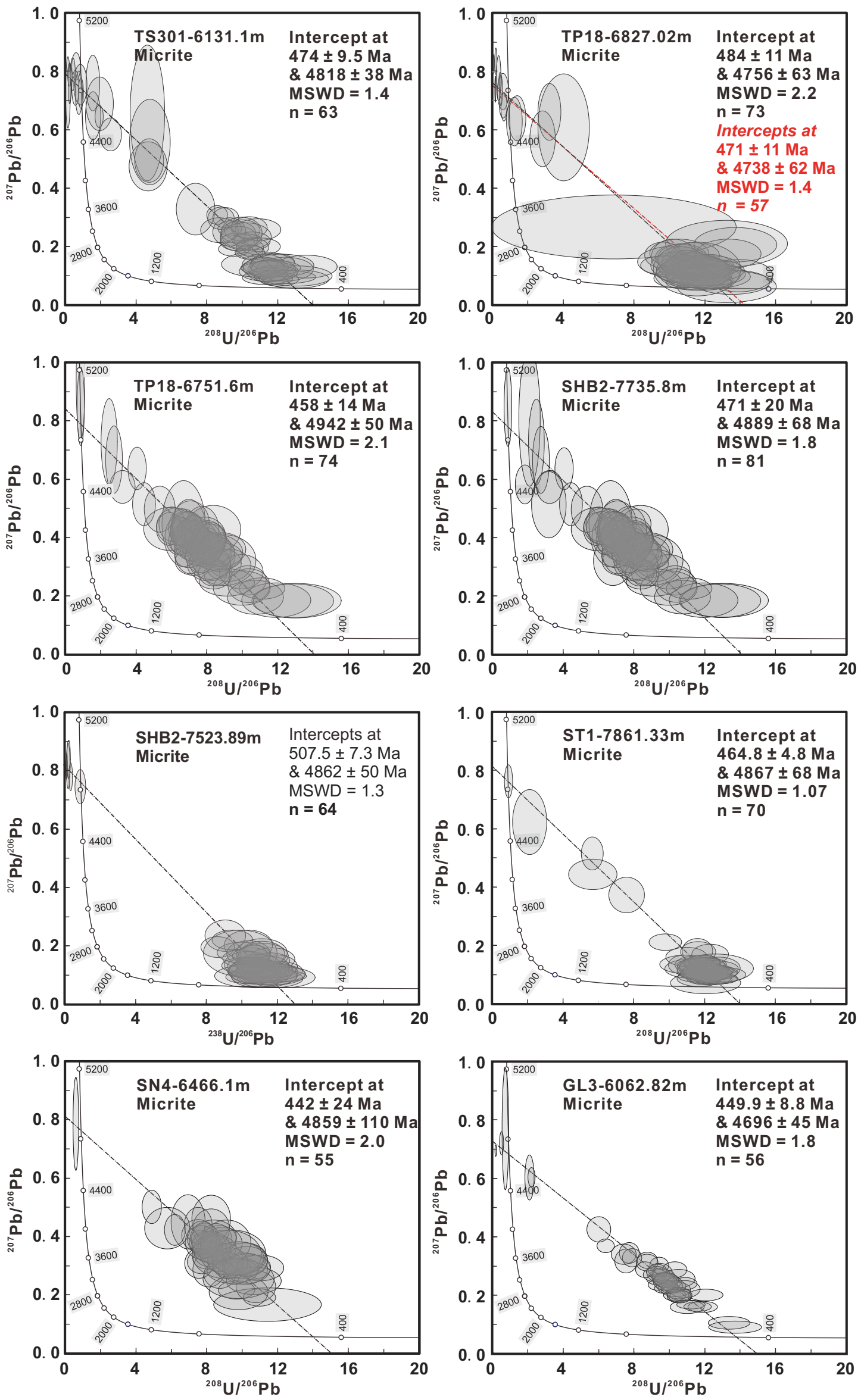

This article is protected by copyright. All rights reserved. 


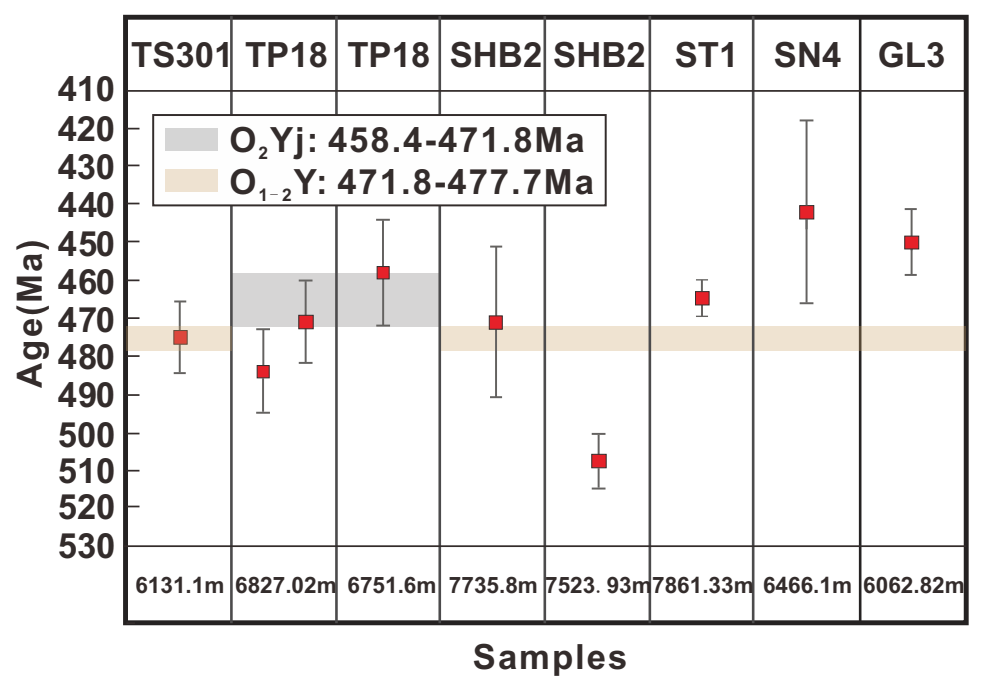

This article is protected by copyright. All rights reserved. 


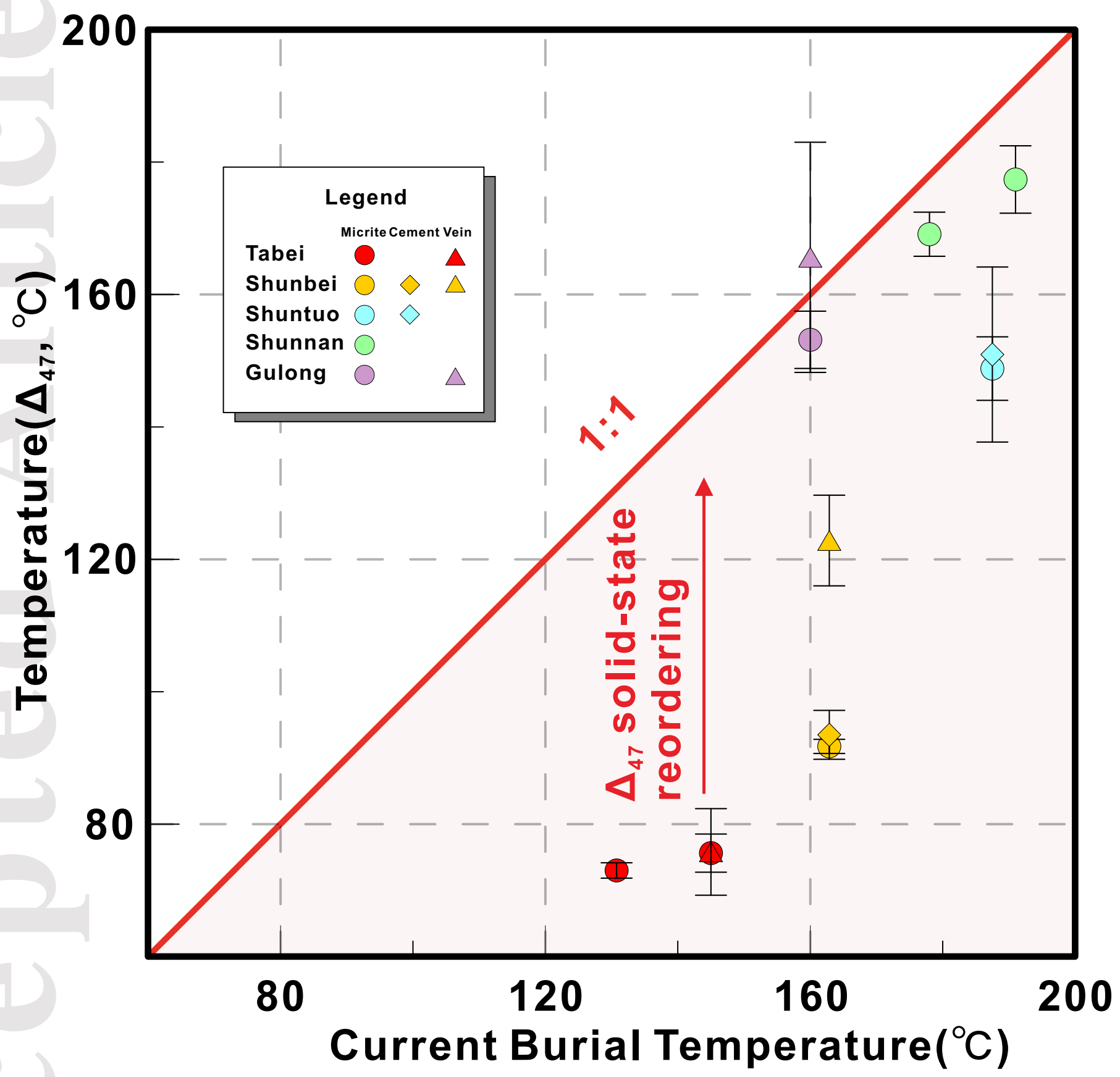

This article is protected by copyright. All rights reserved. 

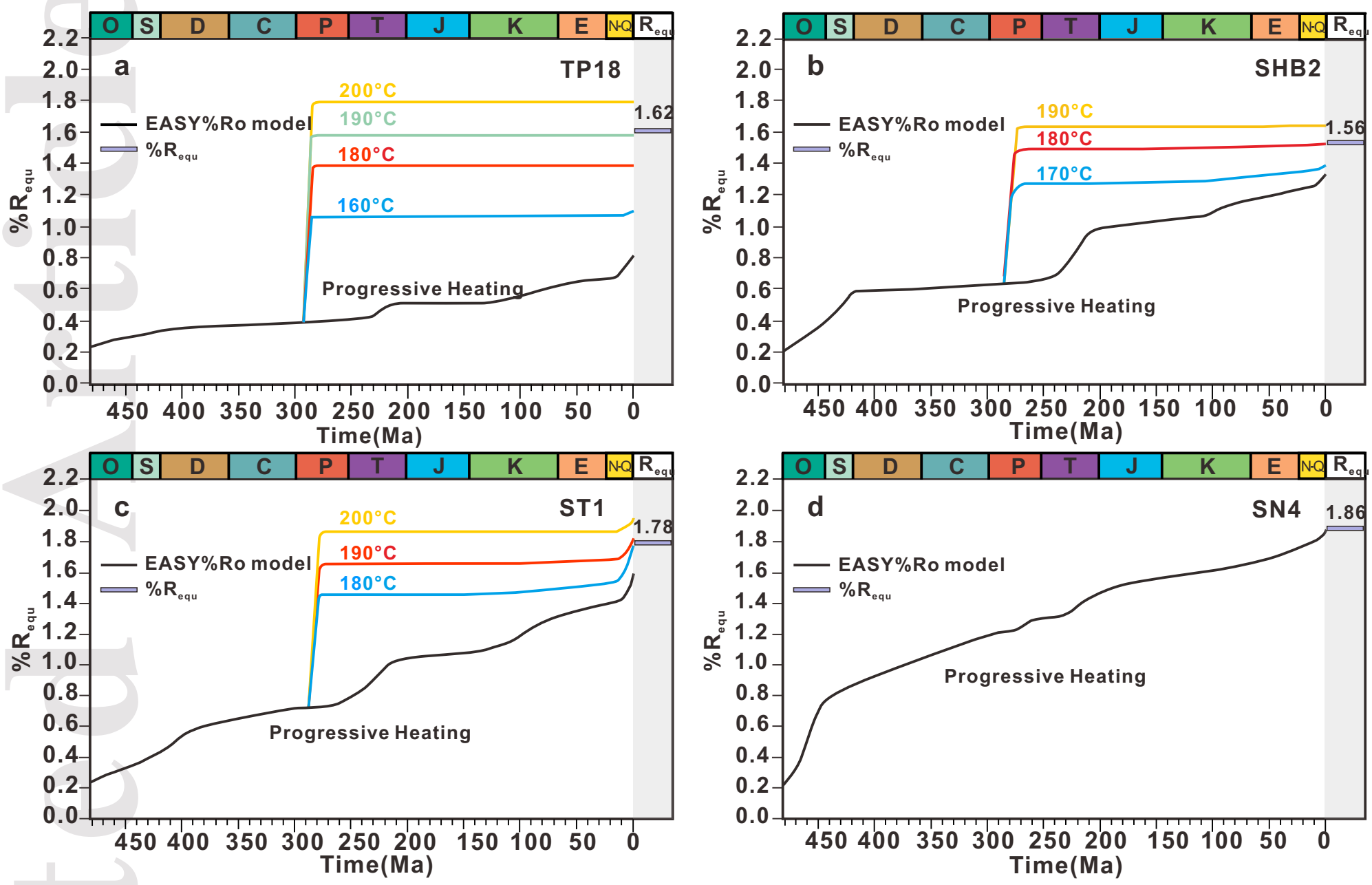

This article is protected by copyright. All rights reserved. 


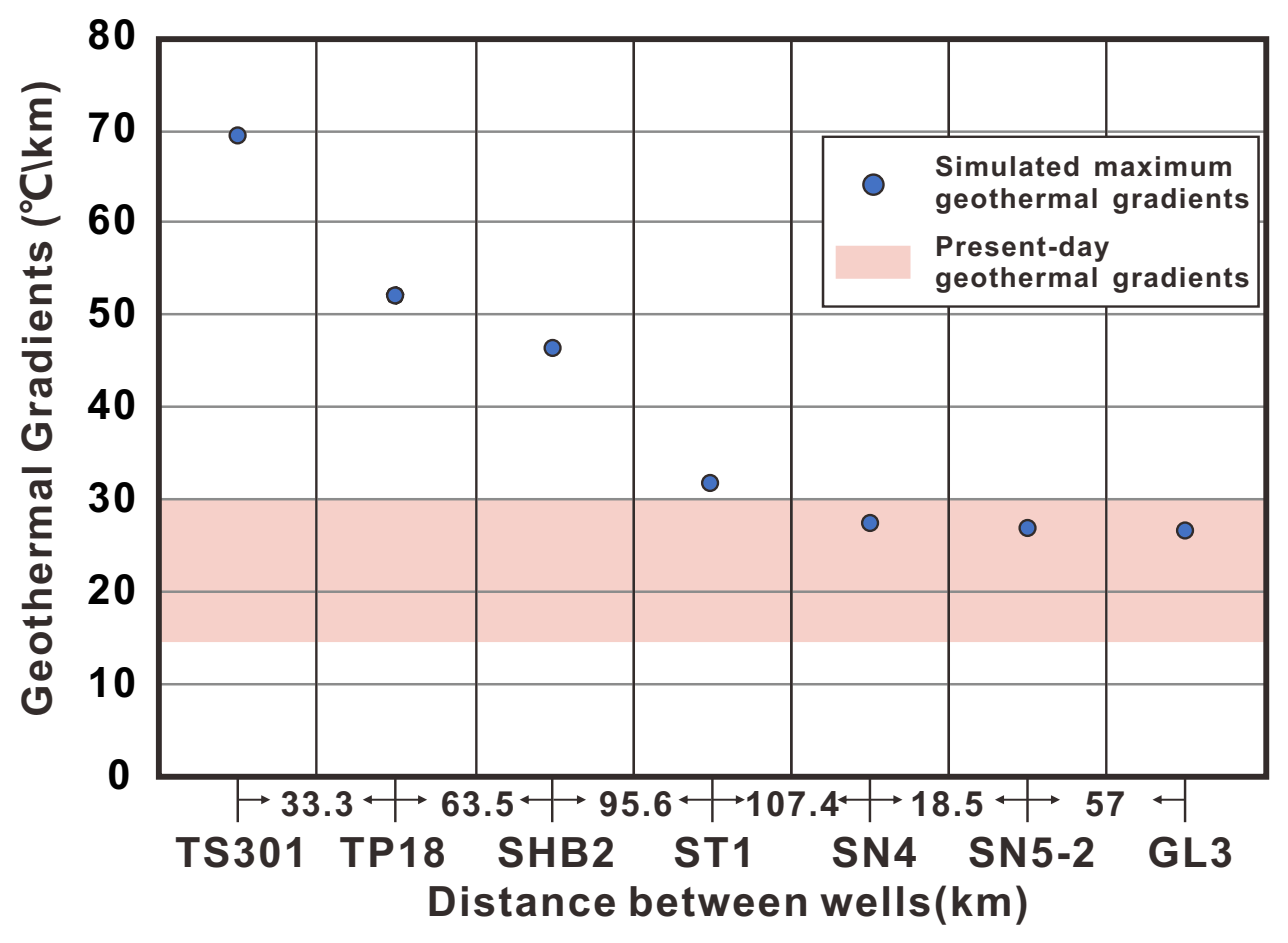

This article is protected by copyright. All rights reserved. 
Stolper and Eiler(2015) model
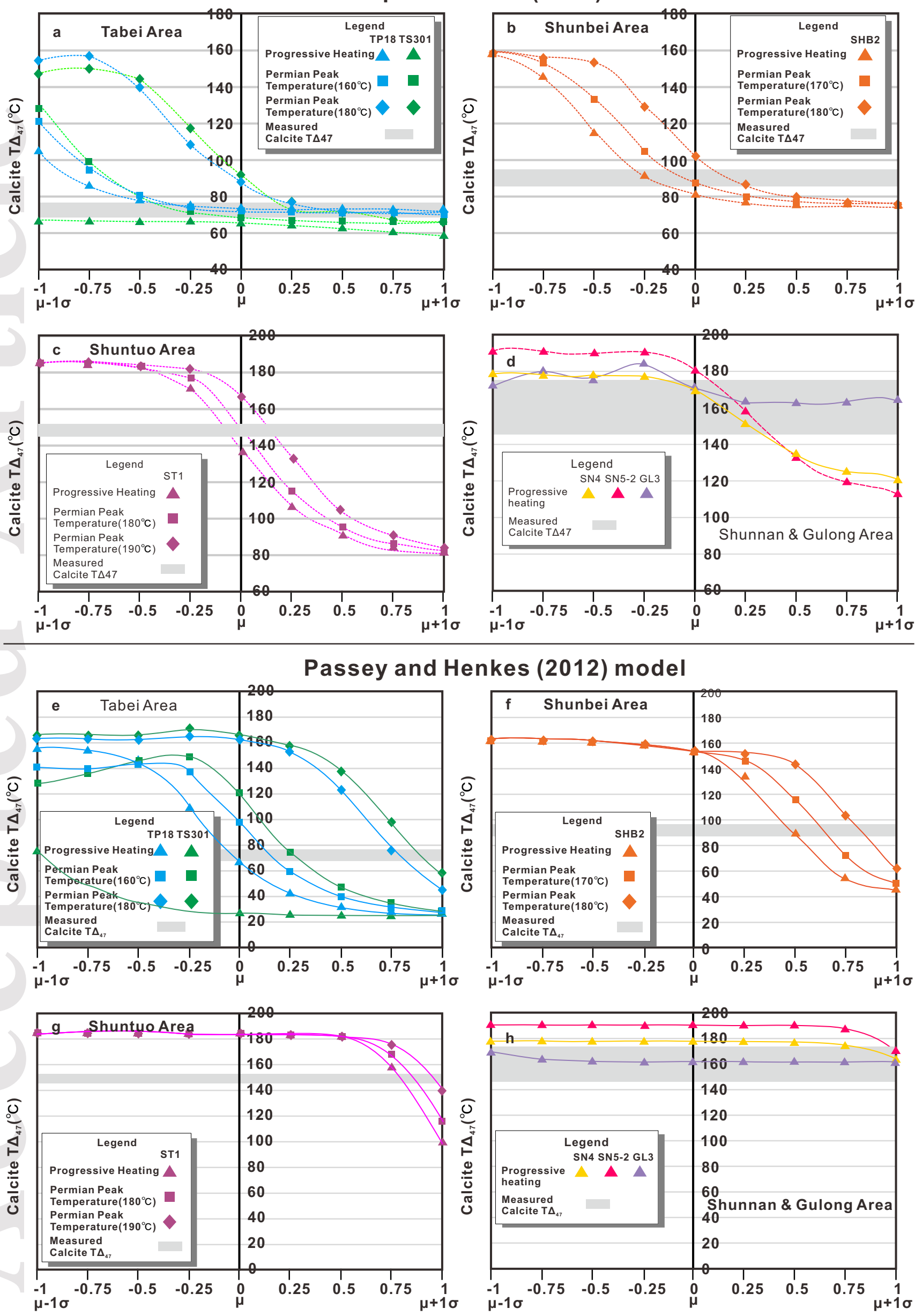

This article is protected by copyright. All rights reserved. 